\title{
Kamila Bigos
}

PhD Candidate, Faculty of Humanities,

\section{The dynamics of the regression of aphasic disorders in a stroke patient}

\begin{abstract}
Aвstract: The most common diseases causing language difficulties of aphasia type include cerebral vascular diseases, including ischaemic strokes. Speech disorders resulting from brain damage are usually dynamic. The clinical picture, and further on, the effective diagnosis and speech therapy of a patient after a neurological incident, is thus greatly influenced both by the circumstances in which the patient found himself and the time factor. The paper presents the dynamics of aphasic disorders in a patient after ischaemic stroke within the left hemisphere. The aim is to draw attention to the changes in the image of aphasic disorders in a 63-year-old man after a neurological incident in which semantic aphasia was diagnosed, which is the evidence of differences in the occurrence of symptoms (including aphasic disorders) in the patient immediately after the stroke and over a dozen months after the incident, after an of intensive speech therapy.
\end{abstract}

KEYWORDs: neurological diseases, stroke, semantic aphasia

\section{Dynamika ustępowania zaburzeń afatycznych u chorego po udarze mózgu}

STRESZCZEnIE: Do najczęstszych jednostek chorobowych powodujących trudności językowe o typie afazji należą choroby naczyniowe mózgu, a wśród nich udary niedokrwienne. Zaburzenia mowy wynikające z uszkodzeń mózgu mają zazwyczaj charakter dynamiczny. Duży wpływ na obraz kliniczny, a dalej - skuteczną diagnozę i terapię logopedyczną pacjenta po przebytym incydencie neurologicznym, mają zatem okoliczności, w jakich znalazł się chory, a także czynnik czasu. W artykule przedstawiono dynamikę ustępowania zaburzeń afatycznych u chorego po udarze niedokrwiennym w obrębie lewej półkuli mózgu. Celem jest zwrócenie uwagi na zmiany w obrazie zaburzeń u 63-letniego mężczyzny po przebytym incydencie neurologicznym, u którego zdiagnozowano afazję semantyczną. Stwierdzono różnice w występowaniu objawów (w tym zaburzeń afatycznych) u pacjenta bezpośrednio po udarze oraz po kilkunastu miesiącach od zachorowania, po intensywnej terapii logopedycznej.

SŁOWA KLUCZOWE: choroby neurologiczne, udar mózgu, afazja semantyczna 
Speech ${ }^{1}$, regarded as the most complex human activity, results from the proper functioning of the entire nervous system ${ }^{2}$; in particular, the brain that is its most important element. The brain performs certain functions that are attributed to the following four lobes within each hemisphere: 1) the frontal lobe - behaviour control, planning, movement control; 2) the parietal lobe - reception of sensory impressions; 3) temporal lobe - recognition of acoustic incentive; and 4) the occipital lobe - perception of visual incentives (Panasiuk, 2013, pp. 39-42).

Although it is assumed that speech activities result from the normative interaction of the entire cerebral cortex, within the left hemisphere of the brain, the so-called speech area can be distinguished that includes: the posterior-lower part of the frontal lobe, the posterior part of the upper and middle temporal gyrus, the area of temporo-parieto-occipital junction, and the medial part of frontal lobe (Prusiński, 1980, p. 71).

The research shows that the involvement of hemispheres in speech activities is unequal - one of them is always dominant over the other, in right-handed people it is usually the left hemisphere of the brain (Walsh, 1998, pp. 354-411). According to the principle of the lateralisation of the function, when the left hemisphere becomes more dominant over the right one, it is not related to the work of right hand and speech, but rather it is the principle of the functional organisation of human cerebral cortex (Łuria, 1976, p. 117). Furthermore, it is widely known that the dominant hemisphere (usually the left one) plays a key function in not only cerebral organisation of speech, but also all the higher mental activities associated with it, such as categorical perception, verbal memory, logical thinking, whereas the subordinate hemisphere (usually the right one) participates in their course to a much lesser extent (Łuria, 1976, p. 117).

As a result of focal brain damage within a dominant hemisphere (usually the middle part of the left hemisphere in right-handed people), aphasia occurs, which, in the second half of the $20^{\text {th }}$ century, Mariusz Maruszewski (1966) defined as "due to organic damage to the relevant brain structures, partial or complete impairment of mechanisms programming speech functions in a human who has already mastered them" (p. 98).

From the point of view adopted in speech therapy, the abovementioned definition most accurately reflects the essence of this speech disorder because it widely

\footnotetext{
${ }^{1}$ I assume that speech is "a set of activities that a person performs with the participation of language, learning about the world, and conveying its interpretation to other participants of social life" (Grabias, 2012, p. 15).

2 The human nervous system is divided into: I) the central nervous system, CNS, that consists of: 1) the spinal cord; 2) the cerebellum that comprises of: a) the brainstem (the medulla oblongata; the pons, the mesencephalon); b) the cerebellum; c) the brain (the diencephalon, the cerebrum); and II) the peripheral nervous system that consists of the ganglia and nerves which are responsible for imparting information from CNS to individual organs (Gołąb, 2004).
} 
and precisely includes all speech disorders with a neurogenic background in it and allows one to distinguish between them; at the same time, it makes it possible to emphasise that aphasia is not the disintegration of the linguistic system, as it has been defined by linguists so far, but rather - a dysfunction of speaking and understanding of speech.

\section{Anatomical and functional basis of semantic aphasia}

Aphasia is a speech disorder resulting from cerebral cortex damage. Aleksander R. Łuria distinguishes three groups of cortical fields: 1) primary fields (projective, primordial), which are responsible for receiving information in the centre, and their damage implies: hearing impairments (the temporal lobe), visual impairments (the occipital lobe), sensory impairments (the parietal lobe); 2) secondary fields (associative/connotational, secondary) that are specialised in the analysis and synthesis of auditory, visual, and sensory sensations stemming from primary fields and determine the recognition of these signals by the brain, and, thus, the damage leads to various types of agnosia; 3 ) tertiary fields (actually, associative fields), whose role is to integrate the information received from secondary fields; located at the junction of three analysers: auditory in the temporal lobe, visual in the occipital lobe, and somaesthetic in the parietal lobe (T-P-O area, temporoparieto-occipitalis) as well as prefrontal area (Łuria, 1976, pp. 17-41).

The author underlines that the paramount principle of cerebral cortex structure is the hierarchical organisation of cortical areas: that is, the responsibility of subsequent fields for the implementation of an increasingly complex synthesis of receiving information; still, the relationships between successive areas are different in the period of ontogenesis. For a small child, the condition for the emergence of secondary fields and, further on, for the proper developing of tertiary fields, the normative structure of secondary fields is necessary (Łuria, 1976, p. 114). It is worth mentioning that tertiary fields are developing exclusively in humans and maturing at the last stage of ontogenesis of the posterior part of the brain - it is believed that the completion of their development and the beginning of the normative one occur only in the seventh year of human life (Łuria, 1976, p. 182).

This article presents a description of disorders in the patient with semantic aphasia resulting from the tertiary fields damage located at the junction of T-P$\mathrm{O}$, whose main function indicates the integration of incentives coming from different analysers.

Cognitive human activity is based on the cooperation of the entire cerebral cortex, where the areas of cortical parts of these analysers are responsible for. 
Euria points out that a significant part of the neurons located at this point are polymodal in nature and respond to complex environmental characteristics (such as spatial location or the number of elements in a set), which the nerve cells forming the primary and secondary areas do not respond to. It is assumed that the most important functions of proper associative fields are: the spatial organisation of stimulations and the transformation of consecutively received signals (successive) into collectively working groups (simultaneous), which results in the synthetic nature of perception. However, the role of the tertiary fields of the posterior of the brain does not focus only on the proper synthesis of directly received information; its other function is the transformation of content from the level of direct visual synthesis to the level of symbolic processes, modifying the meaning of words, complex grammatical, and logical structures, numerical systems, and abstract relations. Luria defines the tertiary fields of the posterior of the cerebral cortex as the apparatuses that are necessary to transform the direct and sensory perception into abstract thinking regulated by the internal patters and to maintain the organised experience in our memory (Łuria, 1976, p. 182).

In case of the tertiary fields of the cerebral cortex damage, which are considered to be the anatomical foundations of the highest forms of human cognition, the principle of lateralisation of higher mental activities becomes important because these areas are basic for the functional organisation of information that reaches the cerebral cortex in terms of speech; the function of the tertiary fields in an adult person, therefore, becomes significantly different in the left hemisphere of the brain (Łuria, 1976, p. 182).

\section{The symptoms of focal brain damage in the temporal-parietal-occipital area}

The focal brain damage in the area of tertiary fields of cerebral cortex are manifested by speech disorders in form of semantic aphasia ${ }^{3}$ characterised by the difficulties in understanding grammatically complex forms of expression (e.g. prepositional phrases, case governments, sentences with syntactic inversion, or constructions in passive voice). This type of aphasia is conditioned by disorders of simulative synthesis - the ability to analyse the receiving linguistic information in terms of logical, grammatical, and semantic aspects simultaneously (Panasiuk, 2013, p. 124).

${ }^{3}$ In the publications devoted to this subject, such terms as amnestic aphasia and nominal aphasia are used to describe this type of aphasia 
Patients have difficulties in understanding the received message (e.g. visual, auditory one) as a whole, whereas the specific characteristic of T-P-O area damage is the loss of sensory spatial synthesis skills - spatial orientation disorders, which, in fact, means that patients have difficulties in finding themselves in the environment. Moreover, they are not able to correctly read and interpret maps or even make their own plan of places that are well-known for them.

In case of deeper disorders, there are also problems with localising objects in space, attempting to imitate the position of a hand (as demonstrated by another person) to build a certain figure from the given elements, that is described as constructional apraxia. Specifically, apparent difficulties are related to the graphic introduction of letters that does not result from the phonemic analysis of the word disorder, but rather results in the incorrect spatial analysis of the lines forming letters, and causes writing impairment (Łuria, 1976, pp. 181-183).

Yet another symptom of the damage in the area at the junction of the temporal, parietal, and occipital lobes within the left hemisphere of the brain are the difficulty with symbolic synthesis (quasi-spatial), which induces problems with the analysis of symbolic relations. Patients have a good understanding of the phrases of colloquial language, but they find complex logical and grammatical structures difficult (e.g. complex syntactic structures, abstract relations, i.e. case governments, prepositional and tense structures, passive voice, syntax inversion). What is more, quasi-spatial disorders are associated with the symptoms of difficulties in performing mathematical operations by patients. The simultaneous synthesis disorder at the mnestic and verbal levels causes significant problems regarding cognitive operations and concrete and image thought processes. Patients have difficulties with not only formulating their thoughts, but also carrying out intellectual activities; while understanding the general sense of sentence, they have considerable difficulties with recognising forms and comparative structures (Łuria, 1976, pp. 181-183).

The third type of disfunctions resulting from the T-P-O area damage within the left hemisphere of the brain encompasses disturbances in verbal memory processes, which are manifested as the difficulties in giving the names of objects (the research shows that the greatest disturbances concern the names of objects, while the second greatest - the characteristics of activities and activities themselves).

Patients usually say words that are similar in terms of semantics, morphology, or phonetics that are presented as verbal and phonemic paraphasia (Euria, 1976, pp. 181-183). 


\section{Exemplification}

The research hereby presented concerns a 63-year-old-man who was admitted to the Stroke and Early Post-Stroke Rehabilitation Department of the Independent Public Clinical Hospital No. 4 in Lublin in February 2019 due to ischemic stroke within the left hemisphere of the brain (the parietal lobe). The man was diagnosed with cerebral atherosclerosis and occlusion of the left internal carotid artery. Previously, the patient had been treated for type 2 diabetes and arterial hypertension. Two months after having a stroke, the man made an appointment at UMCS Logopedics Laboratory located at the Department of Logopedics and Applied Linguistics UMCS in Lublin. Then, the man was diagnosed with semantic aphasia and underwent the proposed speech therapy.

The patient has an academic degree - Master of Science in Civil Engineering at Lublin University of Technology. He has been working as a construction manager for many years. Since the neurological incident occurred, he has not taken up any professional work. Moreover, he and his family frequently go out of town, where he can take care of a garden and continue to construct a holiday house. He spends a plenty of time with his grandchildren as well, which is an additional activity and motivation for him in overcoming the daily difficulties and barriers posed by his linguistic and communicative limits.

In order to present the changes in the aphasic disorders of the patient with semantic aphasia, the results of studies on the understanding of spoken statements have been compiled, which were conducted on the basis of experimental and clinical trials both at the time when the man started therapy and after a year of systematic intensive speech therapy.

\section{Task 1. Listen to the text and answer the questions}

TEXT 1

\footnotetext{
"Good morning."

"Good morning, Mr. Wojtek. What's the matter?"

"I have a high temperature, a sore throat, and a headache."

"Ah, what about a cough or runny nose?"

"I don't have a cough, but I have a runny nose."

"All right, please take off your clothes. I'll examine you, then I'll check your throat." "And?"

"Indeed, your throat is like living fire! It's angina. Where did you catch it? At work?"

"Certainly not. I don't know... Maybe I caught it at my daughter's birthday party. You know, there were a lot of children."
} 
"Probably, yes. I'll prescribe you some antibiotics. Please, take it for seven days. Do you need any sick leave?"

"No, I don't. I haven't been working for a month."

TABLE 1. The understanding of linguistics structures in spoken texts - pragmatic functions of utterances

\begin{tabular}{|c|c|c|c|}
\hline \multirow{2}{*}{$\begin{array}{l}\text { Ordinal } \\
\text { number }\end{array}$} & \multirow[b]{2}{*}{ Question } & \multicolumn{2}{|r|}{ Answer } \\
\hline & & $\begin{array}{l}\text { At the beginning } \\
\text { of speech therapy }\end{array}$ & After a year of speech therapy \\
\hline 1 & $\begin{array}{l}\text { Where does the } \\
\text { conversation take } \\
\text { place? }\end{array}$ & $\begin{array}{l}\text { The thing is that I don't know... } \\
\text { He has a high temperature, } \\
\text { and then he is undressing... } \\
\text { Do I still need to talk? }\end{array}$ & At the doctor's. \\
\hline 2 & $\begin{array}{l}\text { What kind of } \\
\text { symptoms does } \\
\text { the patient have? }\end{array}$ & $\begin{array}{l}\text { Well, there is a sick man, } \\
\text { right..? And then he comes to } \\
\text { the doctor's and the doctor } \\
\text { examines the patient. Oh! } \\
\text { He has a sore throat and the } \\
\text { doctor's examines him. }\end{array}$ & $\begin{array}{l}\text { He has a red throat - the doctor said } \\
\text { so. [B: What about the patient?] He } \\
\text { has a headache and well, he has } \\
\text { a high temperature. [B: All right, } \\
\text { does he have a cough??] No he, } \\
\text { doesn't. He has a runny nose. Ah, } \\
\text { sure, I remember it now! }\end{array}$ \\
\hline 3 & $\begin{array}{l}\text { Does the patient } \\
\text { need a sick leave? }\end{array}$ & $\begin{array}{l}\text { Honestly, I don't remember... } \\
\text { [he wonders] For a couple of } \\
\text { days, I think. }\end{array}$ & $\begin{array}{l}\text { He doesn't need a sick leave, because } \\
\text { he doesn't work any } \\
\text { longer. }\end{array}$ \\
\hline 4 & $\begin{array}{l}\text { What kind of } \\
\text { actions does the } \\
\text { doctor take? }\end{array}$ & $\begin{array}{l}\text { Well, this man comes and } \\
\text { says that he is sick.. }\end{array}$ & $\begin{array}{l}\text { I suppose the doctor advises him to } \\
\text { take some pills. I mean, you know, } \\
\text { antibiotics! [B: And before that?] } \\
\text { Well, he examines him and checks } \\
\text { his throat. }\end{array}$ \\
\hline 5 & $\begin{array}{l}\text { What is the } \\
\text { doctor's advice? }\end{array}$ & Antibiotics? & $\begin{array}{l}\text { Right, well, that's that.. he prescribes } \\
\text { him some antibiotics. }\end{array}$ \\
\hline 6 & $\begin{array}{l}\text { Has the patient } \\
\text { caught the illness } \\
\text { at work? }\end{array}$ & $\begin{array}{l}\text { At work? I don't know, I don't } \\
\text { remember... }\end{array}$ & $\begin{array}{l}\text { No, he hasn't. There was a children's } \\
\text { party and probably he got infected } \\
\text { there. }\end{array}$ \\
\hline 7 & $\begin{array}{l}\text { Is the patient sure } \\
\text { where he became } \\
\text { infected with } \\
\text { angina? }\end{array}$ & Well, probably at work, right? & $\begin{array}{l}\text { I mean... Well, I don't know for sure, } \\
\text { but probably at that party. }\end{array}$ \\
\hline 8 & $\begin{array}{l}\text { How does the } \\
\text { patient feel? } \\
\text { What emotions } \\
\text { does he expe- } \\
\text { rience? }\end{array}$ & $\begin{array}{l}\text { Well, I think he feels bad. } \\
\text { He's sick. }\end{array}$ & $\begin{array}{l}\text { But specifically? This patient? Well, } \\
\text { he feels bad, he has some... heada- } \\
\text { ches... sore throat. } \\
\text { [B: So, what emotions does he expe- } \\
\text { rience? What is he like?] He's so } \\
\text { weary.... Probably he's exhausted. }\end{array}$ \\
\hline
\end{tabular}


Table 1 presents the results of the patient's understanding of pragmatic function of speech, ${ }^{4}$ which was aimed at assessing the diagnosis of intentions received by the interlocutor in the given conversation (Text 1). A study conducted at the time of the beginning of speech therapy indicates considerable disorders in terms of activity discussed. The patient usually gave inadequate answers. He understood the general meaning of the speech, but did not always refer to a specific question. In two cases, the patient did not understand the question $(1,4)$ and as a result, he gave incorrect answers. Moreover, it happened that the patient understood the question, but did not give the correct answer as well. Thus, he answered only one question correctly (5), but he was not sure about his answer. The results of the study repeated a year later clearly show a significant improvement in the understanding of the interlocutor's intentions in the presented dialogue. The patient gave the correct answer to each of the questions but sometimes he needed additional inquiries which he answered more confidently. He was sure about his answers, while his statements were much longer and abundant in content.

\title{
Task 2. Listen to the text and answer the questions
}

\section{Texт 2}

\author{
The Scientific Circle of Theologians \\ at the University of Warsaw \\ is honoured to invite \\ Students of the Faculty of Polish Studies \\ for the performance entitled "Sisyphean Work" \\ that will take place on May 15, 2019 at 6 p.m. \\ in the Main Hall of the Faculty Of Polish Studies of the University of Warsaw \\ at Krakowskie Przedmieście 26/28. \\ You are welcome to join us!
}

In the following attempt, the understanding of spoken text of literal meaning has been assessed (text 2 , table 2 ). ${ }^{5}$ The results indicate that at the beginning

\footnotetext{
${ }^{4}$ The assessment covered the understanding of the pragmatic functions of statements proposed by Stanisław Grabias (1997, 2007, 2019), who enumerates: 1) informative function; 2) operational function; 3) modal function; 4) informative function.

${ }^{5}$ The understanding of the meaning of the texts was assessed in relations to four levels of understanding of expressions, such as: 1) the global level, involving the understanding of the text as a whole; 2) the selective level related to the content of the text and the ability to make selections in order to extract specific facts; 3 ) the specific level, related to the aim of disclosing the meaning of the text by analysing the importance of specific lexical units, explaining metaphors, and drawing conclusions; and 4) the interactive level, referring to the communication situation in which the text is embedded (Wojciechowska, 2015).
} 
K. BIGos: The dynamics of the regression of aphasic disorders in a stroke patient

TABLE 2. The understanding of linguistics structures in spoken texts - a text with a literal meaning

\begin{tabular}{|c|c|c|c|}
\hline \multirow{2}{*}{$\begin{array}{l}\text { Ordinal } \\
\text { number }\end{array}$} & \multirow[b]{2}{*}{ Question } & \multicolumn{2}{|c|}{ Answer } \\
\hline & & $\begin{array}{c}\text { At the beginning of speech the- } \\
\text { rapy }\end{array}$ & After a year of speech therapy \\
\hline 1 & $\begin{array}{l}\text { What type of text } \\
\text { is it? }\end{array}$ & $\begin{array}{l}\text { Well, I don't know.. but, what } \\
\text { are you asking? [B repeats the } \\
\text { question] What type of text... } \\
\text { [he wonders] Well, there is some } \\
\text { information that something is } \\
\text { going to happen and some people } \\
\text { are invited. }\end{array}$ & It's an invitation. \\
\hline 2 & $\begin{array}{l}\text { What is this text } \\
\text { about? What topic } \\
\text { does it cover? }\end{array}$ & $\begin{array}{l}\text { Well, there is some.. I don't } \\
\text { know... something is going to } \\
\text { happen... some performance? } \\
\text { But actually, I don't remember } \\
\text { what kind of. }\end{array}$ & $\begin{array}{l}\text { The Science Circle is to invite, } \\
\text { but I just don't know... for some } \\
\text { spectacle, probably it is entitled } \\
\text { "Sisyphean work." }\end{array}$ \\
\hline 3 & $\begin{array}{l}\text { Where does the } \\
\text { performance take } \\
\text { place? }\end{array}$ & $\begin{array}{l}\text { Oh! I have no idea.. I can't recall. } \\
\text { [B: At theatre or at the Univer- } \\
\text { sity Hall?] There was something } \\
\text { about this University... }\end{array}$ & $\begin{array}{l}\text { Probably at some University } \\
\text { Hall...in Warsaw, certainly. }\end{array}$ \\
\hline 4 & $\begin{array}{l}\text { On which street } \\
\text { is the Faculty of } \\
\text { Polish Studies } \\
\text { of the University } \\
\text { of Warsaw located? }\end{array}$ & $\begin{array}{l}\text { [He repeats the question and } \\
\text { wonders for a bit longer] Oh, } \\
\text { well.. I'm not sure if I caught } \\
\text { that... }\end{array}$ & $\begin{array}{l}\text { I know that this informa- } \\
\text { tion was given, but I couldn't } \\
\text { recall... [he wonders] ...There } \\
\text { is also such a street in the Old } \\
\text { Town in Lublin. [B: Kra...] Kra- } \\
\text { kowskie Przedmieście, right! }\end{array}$ \\
\hline 5 & $\begin{array}{l}\text { What does "sisy- } \\
\text { phean work" } \\
\text { mean? }\end{array}$ & $\begin{array}{l}\text { Well, sisyphean.. How can } \\
\text { I explain that? [he wonders] Is } \\
\text { it not satisfactory? }\end{array}$ & $\begin{array}{l}\text { It is work which does not give } \\
\text { neither satisfaction nor effects. }\end{array}$ \\
\hline 6 & $\begin{array}{l}\text { Will the show be } \\
\text { staged by profes- } \\
\text { sional actors? }\end{array}$ & Yes, it will be staged by actors. & $\begin{array}{l}\text { No, it won't. It was some kind of } \\
\text { theatrical circle.[B: So, who are } \\
\text { these actors?] Well, who they } \\
\text { are ...probably some students. }\end{array}$ \\
\hline 7 & $\begin{array}{l}\text { What is the purpo- } \\
\text { se of this text? }\end{array}$ & $\begin{array}{l}\text { What is the purpose of it? } \\
\text { I don't know... I don't really } \\
\text { know how to say it. }\end{array}$ & $\begin{array}{l}\text { The purpose of the text is to } \\
\text { encourage people to come to this } \\
\text { spectacle. }\end{array}$ \\
\hline 8 & $\begin{array}{l}\text { Who is the addres- } \\
\text { see of this text? }\end{array}$ & $\begin{array}{l}\text { Probably, the person who wrote } \\
\text { it. }\end{array}$ & $\begin{array}{l}\text { Well, all of the students who are } \\
\text { willing to come to this perfor- } \\
\text { mance. }\end{array}$ \\
\hline
\end{tabular}

SOURCE: Own study.

of the therapeutic process, the patient understood the general meaning of the text, but he had difficulties in answering the questions - if he manages to give the correct answers (questions 2,5), he is not sure about them. He usually 
answered inadequately or did not answer at all. After a year of intensive work, the results are completely different. The patient answered correctly all questions. What is more, in order to get more precise information, the interlocutor asked an additional question or gave some clues (questions 4,6); as a result, the patient answered correctly. The patient's difficulties were related to the recollecting some specific information included in text rather than to its understanding.

\section{Task 3. Listen to the text and answer the question}

\section{Texт 3}
"Why do you weep?" inquired the young siskin of the old,
"You're more comfortable in this cage than out in the cold."
"You were born caged," said the elder, "this was your morrow;
"I was free, now I'm caged-hence the cause of my sorrow."
Ignacy Krasicki, Birds in a Cage

TABLE 3. The understanding of linguistic structures in spoken texts - text with the metaphorical meaning

\begin{tabular}{|c|c|c|c|}
\hline \multirow{2}{*}{$\begin{array}{l}\text { Ordinal } \\
\text { number }\end{array}$} & \multirow[b]{2}{*}{ Question } & \multicolumn{2}{|c|}{ Answer } \\
\hline & & $\begin{array}{l}\text { At the beginning } \\
\text { of speech therapy }\end{array}$ & At a year of speech therapy \\
\hline 1 & $\begin{array}{l}\text { What kind of } \\
\text { text is it? }\end{array}$ & $\begin{array}{l}\text { Oh my God, I mean... there } \\
\text { were some birds. }\end{array}$ & Krasicki's fairy tale. \\
\hline 2 & $\begin{array}{l}\text { What is this } \\
\text { text about? } \\
\text { What kind of } \\
\text { topic does it } \\
\text { cover? }\end{array}$ & $\begin{array}{l}\text { The thing is that there are some } \\
\text { old and young birds. Well, one } \\
\text { is like that.. let's say it's not free, } \\
\text { and what else... I think that's } \\
\text { all. }\end{array}$ & $\begin{array}{l}\text { So, there is an old bird, let's call it } \\
\text { like that. And there is the point that } \\
\text { there is also another bird that has } \\
\text { been in slavery and it is difficult for } \\
\text { it to understand that someone who } \\
\text { was once free is suddenly not any } \\
\text { more. }\end{array}$ \\
\hline 3 & $\begin{array}{l}\text { What birds are } \\
\text { the protagonists } \\
\text { of the text? }\end{array}$ & $\begin{array}{l}\text { Well, honestly, I don't really } \\
\text { remember... }\end{array}$ & The siskins. \\
\hline 4 & $\begin{array}{l}\text { Where are the } \\
\text { birds? }\end{array}$ & $\begin{array}{l}\text { The thing is that one of those } \\
\text { birds that feels... well, let's say it } \\
\text { doesn't feel very good. }\end{array}$ & They are caged. \\
\hline 5 & $\begin{array}{l}\text { What period in } \\
\text { the history of } \\
\text { Poland does the } \\
\text { text concern? }\end{array}$ & $\begin{array}{l}\text { The history of Poland? Actual- } \\
\text { ly, I don't know how to say it... } \\
\text { because this bird is lonely. }\end{array}$ & $\begin{array}{l}\text { Well, that's really interesting... And } \\
\text { was it written there? It was happe- } \\
\text { ned when Poland was in captivity, } \\
\text { but how to say it... } \\
\text { [B: When Poland was under...] Oh, } \\
\text { when Poland was under occupation. }\end{array}$ \\
\hline
\end{tabular}


Table 3 (cont.)

\begin{tabular}{|c|l|l|l|}
\hline 6 & $\begin{array}{l}\text { What is the } \\
\text { moral of the } \\
\text { story? }\end{array}$ & $\begin{array}{l}\text { The moral? One of these birds, } \\
\text { let's assume that it's happy, but } \\
\text { it's not free, so that's all, I guess. }\end{array}$ & $\begin{array}{l}\text { I don't really know what is the } \\
\text { moral of the story... [B: You have } \\
\text { already said a little, but now } \\
\text { please refer to the occupation] You } \\
\text { know, I understand the content of } \\
\text { this text, but I don't know how to } \\
\text { define it... They longed for freedom, } \\
\text { didn't they? }\end{array}$ \\
\hline 7 & $\begin{array}{l}\text { What is the } \\
\text { purpose of the } \\
\text { text? }\end{array}$ & $\begin{array}{l}\text { You know, it's some kind of } \\
\text { a metaphor, because one } \\
\text { of these birds was relocated, } \\
\text { I mean, I don't explain it well, } \\
\text { but.. [he asks about the appe- } \\
\text { arance of the birds] I don't } \\
\text { remember how it was with this } \\
\text { poem, because before... I mean, } \\
\text { I know that he's been there befo- } \\
\text { re, but I don't really know how } \\
\text { to explain it right now. }\end{array}$ & $\begin{array}{l}\text { The purpose of the text is to appre- } \\
\text { ciate freedom, but I'm not sure if it's } \\
\text { that's the point? }\end{array}$ \\
\hline 8 & $\begin{array}{l}\text { Who could be } \\
\text { the addressee } \\
\text { of the text? }\end{array}$ & $\begin{array}{l}\text { The addressee? To be honest, } \\
\text { Idon't know really. }\end{array}$ & People who are not free, aren't they? \\
\hline
\end{tabular}

SOURCE: Own study.

Table 3 includes the results of the study of the understanding of a spoken text with the metaphorical meaning (text 3 ). The answers collected at the beginning of speech therapy indicate that the patient did not understand the text that was read to him. Although he strived to analyse the discussed text, he did not fully answer any of the questions. He interpreted the poem literally, recognising its global significance, but he did not notice its metaphorical significance. A year later, the picture of the disorders changed significantly - they concerned only the interactive level and in part the detailed one (in terms of drawing conclusions). The patient answered most of the questions correctly, confidently, and decisively.

\section{Task 4. Listen to the sentences and answer the questions}

1. Jan was praised by Maciek.

2. Anna was offended by Maria.

3. Janusz was asked for help by Thomas.

4. Wojtek was saddened by Ola.

5. Karol was signed up on the list by Jacek.

6. Kasia was escorted to the kindergarten by Basia.

7. Tomek was invited by Wojtek. 
8. Jaś was punished by Waldek.

9. Adam was introduced to Ola's parents by her.

10. Kuba was mocked by Bartek.

TABLE 4. The understanding of linguistics structures in spoken texts - passive voice

\begin{tabular}{|c|c|c|c|}
\hline \multirow{2}{*}{$\begin{array}{c}\text { Ordinal } \\
\text { numer }\end{array}$} & \multirow[b]{2}{*}{ Question } & \multicolumn{2}{|c|}{ Answer } \\
\hline & & $\begin{array}{l}\text { At the beginning of speech } \\
\text { therapy }\end{array}$ & After a year of speech therapy \\
\hline 1 & $\begin{array}{l}\text { Who received the } \\
\text { praise? }\end{array}$ & $\begin{array}{l}\text { Sorry, what did you say? [he } \\
\text { repeats the sentence] Well, } \\
\text { it was Maciek. }\end{array}$ & $\begin{array}{l}\text { [He repeats the sentence] Well, } \\
\text { it was Maciek, wasn't it? }\end{array}$ \\
\hline 2 & $\begin{array}{l}\text { Who was offen- } \\
\text { ded? }\end{array}$ & $\begin{array}{l}\text { [He repeats the sentence } \\
\text { many times] Anna? But I'm } \\
\text { guessing. }\end{array}$ & [He repeats the questions] Anna. \\
\hline 3 & $\begin{array}{l}\text { Who asked for } \\
\text { help? }\end{array}$ & $\begin{array}{l}\text { [He repeats the sentence] } \\
\text { One moment please... Janusz. }\end{array}$ & $\begin{array}{l}\text { [He repeats the question] Was it } \\
\text { Tomek? }\end{array}$ \\
\hline 4 & Who was sad? & So, Ola is sad. & $\begin{array}{l}\text { [He answers without hesitation] } \\
\text { Wojtek. }\end{array}$ \\
\hline 5 & $\begin{array}{l}\text { Who was signed } \\
\text { up on the list? }\end{array}$ & $\begin{array}{l}\text { [He wonders for a while and } \\
\text { repeats a question] Well, } \\
\text { Jacek was on the list. }\end{array}$ & [He thinks for a while] Karol. \\
\hline 6 & $\begin{array}{l}\text { Who stayed in the } \\
\text { kindergarten? }\end{array}$ & $\begin{array}{l}\text { [He repeats the sentence] } \\
\text { Was it Basia? I don't know, } \\
\text { I don't quite understand it. }\end{array}$ & [He repeats] You know, Kasia. \\
\hline 7 & Who had a visitor? & Well, maybe Wojtek. & [He repeats and wonders] Tomek. \\
\hline 8 & $\begin{array}{l}\text { Who got the } \\
\text { penalty? }\end{array}$ & $\begin{array}{l}\text { [He repeats the sentence] } \\
\text { To be honest, I don't really } \\
\text { understand it... }\end{array}$ & $\begin{array}{l}\text { [He repeats the sentence three } \\
\text { times] Was it Jaś? }\end{array}$ \\
\hline 9 & $\begin{array}{l}\text { Who did the } \\
\text { parents know? }\end{array}$ & $\begin{array}{l}\text { Oh my God.. I don't know... } \\
\text { probably Ola. To be honest, } \\
\text { I'm just guessing. I don't } \\
\text { understand it and why it's } \\
\text { like that. }\end{array}$ & [He repeats the sentence] Adam. \\
\hline 10 & $\begin{array}{l}\text { Who was lau- } \\
\text { ghing? }\end{array}$ & Kuba was laughing. & $\begin{array}{l}\text { [He repeats the sentence] Kuba? } \\
\text { No, he wasn't... Kuba was mocked... } \\
\text { [he wonders] So it was Bartek. }\end{array}$ \\
\hline
\end{tabular}

SOURCE: Own study.

In this task (table 4), the understanding of passive syntax constructions was assessed. At the beginning of speech therapy, the patient had great difficulty in understanding this type of structure. It happened that he gave the correct answer to the question; however, as a result of a lucky guess and not understanding the 
sentence. A year later, there was a significant improvement in this activity. Due to thorough analysis of the sentence heard, the patient was able to answer most of the questions. However, it was not an easy task for him and he repeated the phrase several times, but he usually gave accurate answers. It is also worth mentioning that the difficulties with understanding the described structures have decreased significantly when the patient used the graphic pattern of the sentence.

\section{Task 5. Listen to the sentences and answer the questions}

1. Before I get home, I'll do the shopping.

2. After buying the dress, I chose shoes.

3. Before Kasia went to school, she had walked the dog.

4. After watching the movie, I read a book.

5. After the renovation of the flat, they threw out old furniture.

6. Before she ironed the shirt, she had cleaned the room.

7. After washing her hair, she painted her nails.

8. After watering the flowers, she read the newspaper.

9. Before I started studying, I had cleaned the flat and threw rubbish.

10. After drinking coffee, he watered the garden.

TABLE 5. The understanding of linguistics structures in spoken texts - syntactic inversion

\begin{tabular}{|c|l|l|l|}
\hline \multirow{2}{*}{$\begin{array}{c}\text { Ordinal } \\
\text { number }\end{array}$} & \multicolumn{1}{|c|}{ Question } & \multicolumn{2}{|c|}{ Answer } \\
\cline { 2 - 4 } 1 & $\begin{array}{l}\text { What will I do } \\
\text { first? }\end{array}$ & $\begin{array}{l}\text { [He repeats the sentence]... Will } \\
\text { Igo home? }\end{array}$ & $\begin{array}{l}\text { [He repeats the sentence] Well, } \\
\text { I'll do the shopping first. }\end{array}$ \\
\hline 2 & $\begin{array}{l}\text { What did I do } \\
\text { next? }\end{array}$ & $\begin{array}{l}\text { [He repeats the sentence] ... Did } \\
\text { I chose shoes? }\end{array}$ & $\begin{array}{l}\text { Once again, please. [B repeats the } \\
\text { sentence] I chose shoes. }\end{array}$ \\
\hline 3 & $\begin{array}{l}\text { What did she } \\
\text { do first? }\end{array}$ & $\begin{array}{l}\text { [He repeats the sentence] Did she } \\
\text { walk her dog? But I don't know, } \\
\text { Idon't really understand... }\end{array}$ & She walked her dog. \\
\hline 5 & $\begin{array}{l}\text { What did he } \\
\text { do first? }\end{array}$ & $\begin{array}{l}\text { Did he watch a movie? I'm just } \\
\text { guessing... }\end{array}$ & $\begin{array}{l}\text { Did he read a book? [He repeats } \\
\text { the sentence and wonders] No, } \\
\text { no, he watched a movie! }\end{array}$ \\
\hline 6 & $\begin{array}{l}\text { What did they } \\
\text { do later? }\end{array}$ & $\begin{array}{l}\text { They probably got rid of the old } \\
\text { furniture. }\end{array}$ & $\begin{array}{l}\text { Well, it was a renovation of the } \\
\text { flat, and then they got rid of the } \\
\text { furniture. It was furniture. }\end{array}$ \\
\hline 7 & $\begin{array}{l}\text { What did she } \\
\text { do later? }\end{array}$ & $\begin{array}{l}\text { Did she vacuum the room? } \\
\text { do first? }\end{array}$ & $\begin{array}{l}\text { [He repeats the sentence and } \\
\text { request to read again] } \\
\text { Did she vacuum the room? } \\
\text { Idon't really get it... }\end{array}$ \\
\hline
\end{tabular}


Table 5 (cont.)

\begin{tabular}{|c|l|l|l|}
\hline 8 & $\begin{array}{l}\text { What did she } \\
\text { do later? }\end{array}$ & $\begin{array}{l}\text { Oh my God, I don't really know.. } \\
\text { let's say that she read a newspaper. }\end{array}$ & $\begin{array}{l}\text { [He repeats the sentence] So she } \\
\text { read a newspaper later. }\end{array}$ \\
\hline 9 & $\begin{array}{l}\text { What did I do } \\
\text { first? }\end{array}$ & Before... she was studying. & She cleaned the room. \\
\hline 10 & $\begin{array}{l}\text { What did he } \\
\text { do later? }\end{array}$ & $\begin{array}{l}\text { Did he water a garden? But again, } \\
\text { I'm just guessing. }\end{array}$ & $\begin{array}{l}\text { Did he drink a coffee? [I repe- } \\
\text { at the sentence] I don't know, he } \\
\text { drank a coffee first and then he } \\
\text { watered the garden, and I don't } \\
\text { know what happened next. }\end{array}$ \\
\hline
\end{tabular}

Source: Own study.

Table 5 includes the results of the understanding of sentences with syntactic inversion. In case of this task, there is also a noticeable dynamics of disappearing understanding disorders. At the beginning of speech therapy, the patient had a great difficulty with syntactic inversion and he was not sure of his answers altogether; moreover, each of them was only an attempt to guess a complicated riddle. After a year of intensive work, there was a significant improvement in the understanding of this type of constructions; however, the patient put a lot of effort in order to accomplish the task - he kept repeating each sentence many times and analysed it. As before, the task became less complicated when the patient read the given sentences by himself.

\section{Task 6. Listen to the sentences and say how you understand them}

TABLE 6. The understanding of linguistics structures in spoken texts - double negative sentences

\begin{tabular}{|c|l|l|l|}
\hline \multirow{2}{*}{$\begin{array}{c}\text { Ordinal } \\
\text { number }\end{array}$} & \multicolumn{1}{|c|}{ Sentence } & \multicolumn{1}{|c|}{$\begin{array}{c}\text { At the beginning } \\
\text { of speech therapy }\end{array}$} & \multicolumn{1}{|c|}{ After a year of speech therapy } \\
\cline { 3 - 4 } & $\begin{array}{l}\text { I don't believe in } \\
\text { anything. }\end{array}$ & $\begin{array}{l}\text { I don't believe in anything? } \\
\text { So, in anything. }\end{array}$ & $\begin{array}{l}\text { Well, he doesn't believe in any- } \\
\text { thing. }\end{array}$ \\
\hline 2 & $\begin{array}{l}\text { It's not true that } \\
\text { I will not go to the } \\
\text { cinema. }\end{array}$ & He won't go to the cinema. & $\begin{array}{l}\text { He won't go to that cinema. He } \\
\text { won't go at all... though, do I know } \\
\text { it... he will probably go. }\end{array}$ \\
\hline 3 & $\begin{array}{l}\text { I have never been } \\
\text { to the Netherlands. }\end{array}$ & $\begin{array}{l}\text { She has never been to the } \\
\text { Netherlands. }\end{array}$ & $\begin{array}{l}\text { She has never been to this Nether- } \\
\text { lands. }\end{array}$ \\
\hline 4 & $\begin{array}{l}\text { No one is going on } \\
\text { the trip. }\end{array}$ & $\begin{array}{l}\text { Well, it means that no one is } \\
\text { going or everyone? }\end{array}$ & So, no one is going and that's it. \\
\hline 5 & $\begin{array}{l}\text { I don't wear } \\
\text { uncomfortable } \\
\text { shoes. }\end{array}$ & $\begin{array}{l}\text { So, it means that I don't wear } \\
\text { comfortable ones. }\end{array}$ & I wear comfortable shoes. \\
\hline
\end{tabular}


Table 6 (cont.)

\begin{tabular}{|c|c|c|c|}
\hline 6 & No one knows. & Well, no one knows. & No one knows and that's it. \\
\hline 7 & $\begin{array}{l}\text { I can clean up care- } \\
\text { fully }\end{array}$ & She clean up carelessly. & Well, I'm cleaning up badly. \\
\hline 8 & $\begin{array}{l}\text { It is impossible for } \\
\text { her not to do her } \\
\text { homework. }\end{array}$ & $\begin{array}{l}\text { She probably always does her } \\
\text { homework. }\end{array}$ & Well, she did her homework. \\
\hline 9 & $\begin{array}{l}\text { There is no indica- } \\
\text { tion of it. }\end{array}$ & Is there any indication of it? & $\begin{array}{l}\text { [He repeats the sentence] Well, } \\
\text { nothing had happened. }\end{array}$ \\
\hline 10 & $\begin{array}{l}\text { No one has any- } \\
\text { thing to do with it. }\end{array}$ & $\begin{array}{l}\text { Does anyone have anything } \\
\text { to say? }\end{array}$ & $\begin{array}{l}\text { Well, someone can speak. And } \\
\text { nooo! It is my business and no one } \\
\text { has anything to do with it. }\end{array}$ \\
\hline
\end{tabular}

SOURCE: Own study.

The understanding of sentences with double negatives, that is the subject of the study in the following attempt (table 6), is difficult not only for patient with aphasia. From the point of view adopted in formal logic, double negation means a true statement (Stanosz, 2005), which, in turn, is not always confirmed in Polish. At the beginning of the speech therapy, the examined patient had considerable difficulties in understanding this type of structure. He read less than half of sentences correctly, and was unsure of his answers. After a year of therapeutic work, the situation changed. The examined patient correctly recognised the meaning of most of the given structures. Even if he was wrong, after a deeper analysis he changed his mind and also changed his statement into the correct one.

\section{Task 7. Listen to the descriptions of the people and tell us who they are for you}

TABLE 7. The understanding of linguistics structures in spoken texts - case governments

\begin{tabular}{|c|c|c|c|}
\hline \multirow{2}{*}{$\begin{array}{l}\text { Ordinal } \\
\text { number }\end{array}$} & \multirow[b]{2}{*}{ Person } & \multicolumn{2}{|c|}{ Answer } \\
\hline & & $\begin{array}{l}\text { At the beginning of speech the- } \\
\text { rapy }\end{array}$ & After a year of speech therapy \\
\hline 1 & $\begin{array}{l}\text { A father's bro- } \\
\text { ther }\end{array}$ & $\begin{array}{l}\text { Well, I don't know if I can han- } \\
\text { dle it... don't know what it's } \\
\text { like... [B: Is this an uncle or a } \\
\text { grandpa?] Well, maybe } \\
\text { a grandpa, isn't it? But I don't } \\
\text { know, I don't understand it at } \\
\text { all... }\end{array}$ & An uncle. \\
\hline
\end{tabular}


Table 7 (cont.)

\begin{tabular}{|c|c|c|c|}
\hline 2 & A mother's sister & $\begin{array}{l}\text { [He repeats the phrase several } \\
\text { times] I don't know, I have no } \\
\text { idea. [B: Is this grandma or } \\
\text { aunt?] Will it be something like } \\
\text { that? [He repeats the phrase } \\
\text { again] No, well.. mother's sister... } \\
\text { then... well, that's this mother's } \\
\text { sister, but I don't know how to } \\
\text { call it [B: You mean a grandma } \\
\text { or an aunt?] A grandma or an } \\
\text { aunt... Well, maybe it's grand- } \\
\text { ma, but I don't know, I can't be } \\
\text { sure why it's like that. }\end{array}$ & [He repeats a phrase.] An aunt. \\
\hline 3 & A mother's son & $\begin{array}{l}\text { Who could it be? I don't know, } \\
\text { I can't guess. [He wonders; } \\
\text { B: Is this a brother or a cou- } \\
\text { sin?] Well, maybe a brother... } \\
\text { [B: Yes, he is!] Well, yes, but you } \\
\text { have to guess that, but I don't } \\
\text { know... I can't. I don't under- } \\
\text { stand it at all... }\end{array}$ & $\begin{array}{l}\text { [He repeats the sentence] Is he an } \\
\text { uncle? No, he isn't... My mother's } \\
\text { son... Me? [B: You too, but also } \\
\text { who...?] No, wait a minute... } \\
\text { Is this a brother? }\end{array}$ \\
\hline 4 & $\begin{array}{l}\text { A wife's grand- } \\
\text { son }\end{array}$ & $\begin{array}{l}\text { Oh my God... [He repeats the } \\
\text { sentence and wonders] Well, } \\
\text { I just don't know how to define } \\
\text { it... I do not understand your } \\
\text { questions. }\end{array}$ & $\begin{array}{l}\text { [He repeats the phrase] Well, tha- } \\
\text { t's my... [he repeats the phrase] } \\
\text { Well, this is A.*, I know who it is. } \\
\text { Well, that's my granddaughter. }\end{array}$ \\
\hline 5 & $\begin{array}{l}\text { A brother's } \\
\text { father }\end{array}$ & $\begin{array}{l}\text { Is this an uncle? Not really? [he } \\
\text { repeats the phrase several times] } \\
\text { Maybe is this an uncle? No, is } \\
\text { not an uncle? I don't know what } \\
\text { it's like. }\end{array}$ & $\begin{array}{l}\text { Is this an uncle? Something like } \\
\text { that. }\end{array}$ \\
\hline 6 & A mother's sister & $\begin{array}{l}\text { I got confused... Isn't it a grand- } \\
\text { ma? }\end{array}$ & $\begin{array}{l}\text { This is an aunt. It isn't? But, wait, } \\
\text { I have a sister. H. }{ }^{*} \text { [B: Well, right, } \\
\text { so who is her mom for you? ] Her } \\
\text { mum... [he wonders] Well, it's my } \\
\text { mum, isn't it? [B: Yes, it is!] Right, } \\
\text { why didn't you say so in the first } \\
\text { place? }\end{array}$ \\
\hline 7 & $\begin{array}{l}\text { A father's } \\
\text { mother }\end{array}$ & Maybe is this a grandma? & $\begin{array}{l}\text { [He repeats the phrase] } \\
\text { A grandma. }\end{array}$ \\
\hline 8 & An uncle's son & $\begin{array}{l}\text { [He repeats the phrase several } \\
\text { times] Well, I just don't know } \\
\text { who it is... If this is an uncle's } \\
\text { son, right? Well, I don't know, } \\
\text { really, I can't say that. }\end{array}$ & $\begin{array}{l}\text { [He repeats the phrase several } \\
\text { times] Who is this? [B: Is this a } \\
\text { brother or a cousin?] And, well, } \\
\text { that's a cousin. }\end{array}$ \\
\hline
\end{tabular}


Table 7 (cont.)

\begin{tabular}{|c|l|l|l|}
\hline 9 & $\begin{array}{l}\text { A mother's bro- } \\
\text { ther }\end{array}$ & $\begin{array}{l}\text { Do you still have many of these } \\
\text { examples? I can't really guess.. }\end{array}$ & An uncle. \\
\hline 10 & A father's sister & $\begin{array}{l}\text { Well, this is not a sister for sure, } \\
\text { isn't it? I don't know, maybe is } \\
\text { this a father? }\end{array}$ & $\begin{array}{l}\text { Well, that's probably an aunt } \\
\text { again. }\end{array}$ \\
\hline
\end{tabular}

* The patient gives the name of a member of his family.

SOURCE: Own study.

Table 7 shows the results of the study of understanding the meaning of relations that occur in the examples of case governments ${ }^{6}$. At the time of the beginning of the speech therapy, such constructions were extremely difficult for the patient. In fact, he was unable to correctly recognise any of the given relations. Then, it turned out that the reference to the immediate family members of the patient and their names was helpful. The only compensatory mechanism in this case was the creation of "family trees," thanks to which the patient could understand the correlations that occur in the given relationships. These types of interactions became the basis for understanding such linguistics structures. After a year of speech therapy, the patient made a few mistakes, consciously analysed each structure and usually correctly interpreted it. His answers were thoughtful and he needed a clue less often than before, and if he did, he made a full use of it.

\section{Task 8. Listen to the sentences and answer the questions}

1. Sugar is cheaper than coffee, but more expensive than pudding.

2. A shirt is more expensive than trousers, but cheaper than shoes.

3. Kasia is taller than Basia, but is shorter than Karol.

4. Ania is thicker than Zosia, but thinner than Darek.

5. Julek is older than Maciek, but younger than Ala.

6. A washing machine is cheaper than a refrigerator, but more expensive than a dryer.

7. Basia is younger than Joasia, but older than Ola.

8. Kuba is taller than Tomek, but shorter than Bartek.

9. A labrador is bigger than a mongrel, but it's smaller than a sheepdog.

10. Asia is shorter than Kasia, but taller than Zosia.

${ }^{6}$ Case government is defined as a word association in which a subordinate word takes the case that the parent word requires. 
K. BIGos: The dynamics of the regression of aphasic disorders in a stroke patient

TABLE 8. The understanding of linguistic structures in spoken texts - comparative structures

\begin{tabular}{|c|c|c|c|}
\hline \multirow{2}{*}{$\begin{array}{l}\text { Ordinal } \\
\text { number }\end{array}$} & \multirow[b]{2}{*}{ Question } & \multicolumn{2}{|c|}{ Answer } \\
\hline & & $\begin{array}{l}\text { At the beginning of speech the- } \\
\text { rapy }\end{array}$ & A year after of speech therapy \\
\hline 1 & $\begin{array}{l}\text { What is the } \\
\text { cheapest? }\end{array}$ & $\begin{array}{l}\text { [He laughs] And how do } \\
\text { I know that.. I don't know... }\end{array}$ & $\begin{array}{l}\text { [He writes the question on a piece } \\
\text { of sheet] Is it pudding? }\end{array}$ \\
\hline 2 & $\begin{array}{l}\text { What is the most } \\
\text { expensive? }\end{array}$ & $\begin{array}{l}\text { [He repeats the sentence seve- } \\
\text { ral times] And is it possible to } \\
\text { answer that at all? Can you do } \\
\text { it? }\end{array}$ & $\begin{array}{l}\text { [He writes the sentence on a piece } \\
\text { of sheet] It turns out that shoes. }\end{array}$ \\
\hline 3 & $\begin{array}{l}\text { Who is } \\
\text { of average height? }\end{array}$ & $\begin{array}{l}\text { [He writes the sentence on a } \\
\text { piece of paper] I have no idea, } \\
\text { I don't understand it at all.. }\end{array}$ & $\begin{array}{l}\text { Jesus, without writing it down, } \\
\text { I can't guess! But, well.. this first } \\
\text { girl seems to be of average height. }\end{array}$ \\
\hline 4 & $\begin{array}{l}\text { Who is the ligh- } \\
\text { test? }\end{array}$ & $\begin{array}{l}\text { [He writes the sentence on a } \\
\text { piece of sheet] It turns out that } \\
\text { the third one. }\end{array}$ & Is it Darek? \\
\hline 5 & $\begin{array}{l}\text { Who is the } \\
\text { youngest? }\end{array}$ & $\begin{array}{l}\text { [He writes the question on } \\
\text { a piece of paper] So, it is Julek, } \\
\text { isn't it? }\end{array}$ & Ala is probably the youngest. \\
\hline 6 & $\begin{array}{l}\text { What is on the } \\
\text { average price? }\end{array}$ & $\begin{array}{l}\text { [He writes the sentence on } \\
\text { a piece of paper] } \\
\text { I guess that it is the fridge, but } \\
\text { I could be wrong. }\end{array}$ & $\begin{array}{l}\text { Well, probably it is a washing } \\
\text { machine, but I'm not sure. }\end{array}$ \\
\hline 7 & $\begin{array}{l}\text { Who is the } \\
\text { oldest? }\end{array}$ & $\begin{array}{l}\text { [He writes the sentence on } \\
\text { a piece of paper] } \\
\text { I guess, it is Ola. }\end{array}$ & It is Ola. \\
\hline 8 & $\begin{array}{l}\text { Who is the } \\
\text { shortest? }\end{array}$ & $\begin{array}{l}\text { [He writes the sentence on } \\
\text { a piece of paper] Well, I don't } \\
\text { know, I can't handle with it. }\end{array}$ & It's Tomek, I guess. \\
\hline 9 & $\begin{array}{l}\text { Who is the } \\
\text { smallest? }\end{array}$ & $\begin{array}{l}\text { [He repeats the sentence several } \\
\text { times] Maybe is this mongrel? }\end{array}$ & It is a labrador. \\
\hline 10 & $\begin{array}{l}\text { Who is of } \\
\text { average height? }\end{array}$ & It is Zosia. & Is it Kasia, perhaps? \\
\hline
\end{tabular}

SOURCE: Author's own study.

The table 8 presents the results of the study of understanding the most complex sentences in terms of logical, grammatical, and formal structures, namely, comparative structures. The task 8 turned out to be the most difficult one for the patient - both when he started the speech therapy and after a year. The man's understanding of the comparative structures improved, but after a year they were still very difficult for him. The graphical presentation of sentences turned out to be helpful; consequently, the patient made less mistakes. 
K. BIGos: The dynamics of the regression of aphasic disorders in a stroke patient

\section{Task 9. Follow the instructions}

TABLE 9. The understanding of linguistic structures in spoken texts - prepositional phrases

\begin{tabular}{|c|c|c|c|}
\hline \multirow{2}{*}{$\begin{array}{l}\text { Ordinal } \\
\text { number }\end{array}$} & \multirow[b]{2}{*}{ Instructions } & \multicolumn{2}{|c|}{ The performance of instructions } \\
\hline & & $\begin{array}{l}\text { At the beginning of speech } \\
\text { therapy }\end{array}$ & After a year of speech therapy \\
\hline 1 & $\begin{array}{l}\text { Please put your pen } \\
\text { on the piece of paper. }\end{array}$ & $\begin{array}{l}\text { The patient performs the } \\
\text { activity correctly. }\end{array}$ & $\begin{array}{l}\text { The patient performs the activity } \\
\text { correctly. }\end{array}$ \\
\hline 2 & $\begin{array}{l}\text { Please put your pen } \\
\text { under the piece of } \\
\text { paper. }\end{array}$ & $\begin{array}{l}\text { The patient performs the } \\
\text { activity correctly. }\end{array}$ & $\begin{array}{l}\text { The patient performs the activity } \\
\text { correctly. }\end{array}$ \\
\hline 3 & $\begin{array}{l}\text { Please put the keys } \\
\text { at the bottom of the } \\
\text { page. }\end{array}$ & $\begin{array}{l}\text { The patient performs the } \\
\text { activity correctly. }\end{array}$ & $\begin{array}{l}\text { The patient performs the activity } \\
\text { correctly. }\end{array}$ \\
\hline 4 & $\begin{array}{l}\text { Please put the pen } \\
\text { on the left side of the } \\
\text { paper. }\end{array}$ & $\begin{array}{l}\text { The patient performs the } \\
\text { activity correctly. }\end{array}$ & $\begin{array}{l}\text { The patient performs the activity } \\
\text { correctly. }\end{array}$ \\
\hline 5 & $\begin{array}{l}\text { Please put the keys } \\
\text { between the pen and } \\
\text { the paper. }\end{array}$ & $\begin{array}{l}\text { After thinking for a while, } \\
\text { the patient performs the } \\
\text { activity correctly. }\end{array}$ & $\begin{array}{l}\text { The patient performs the activity } \\
\text { correctly. }\end{array}$ \\
\hline 6 & $\begin{array}{l}\text { Please put the keys on } \\
\text { the piece of paper and } \\
\text { put a pen next to the } \\
\text { keys. }\end{array}$ & The patient needs help. & $\begin{array}{l}\text { The patient performs the activity } \\
\text { correctly. }\end{array}$ \\
\hline 7 & $\begin{array}{l}\text { Please touch the paper } \\
\text { with the pen. }\end{array}$ & $\begin{array}{l}\text { He is mistaken; thanks to } \\
\text { the clue he performs the } \\
\text { activity correctly. }\end{array}$ & $\begin{array}{l}\text { The patient performs the activity } \\
\text { correctly. }\end{array}$ \\
\hline 8 & $\begin{array}{l}\text { After you put the pen } \\
\text { next to the paper, } \\
\text { please put the keys in } \\
\text { front of the paper. }\end{array}$ & The patient needs help. & $\begin{array}{l}\text { After thinking for a while and } \\
\text { with a little help, he performs the } \\
\text { activity correctly. }\end{array}$ \\
\hline 9 & $\begin{array}{l}\text { Before you touch the } \\
\text { keys with the pen, } \\
\text { please put the keys on } \\
\text { the piece of paper. }\end{array}$ & The patient needs help. & The patient needs help. \\
\hline 10 & $\begin{array}{l}\text { Please put the piece } \\
\text { of paper next to the } \\
\text { calendar and then put } \\
\text { the keys in between. }\end{array}$ & The patient needs help. & The patient needs help. \\
\hline
\end{tabular}

SOURCE: Own study. 
The table 9 presents the results of the study of understanding the meaning of prepositional phrases. At the beginning of the speech therapy, the patient was able to perform some simple tasks on his own, but he needed some help in order to follow complicated instructions, requiring logical and grammatical as well as time and space orientation. However, over time, the understanding of these linguistic structures had improved. The patient only needed help with the most complex tasks, including syntactic inversion, and those that had a convoluted logical, grammatical, and formal structure.

\section{Results}

The presented chart shows the ratio of tasks correctly performed by a patient with semantic aphasia; the answers to the individual tasks at the beginning of therapeutic treatment are compared to those performed correctly after a year of intensive work with the patient.

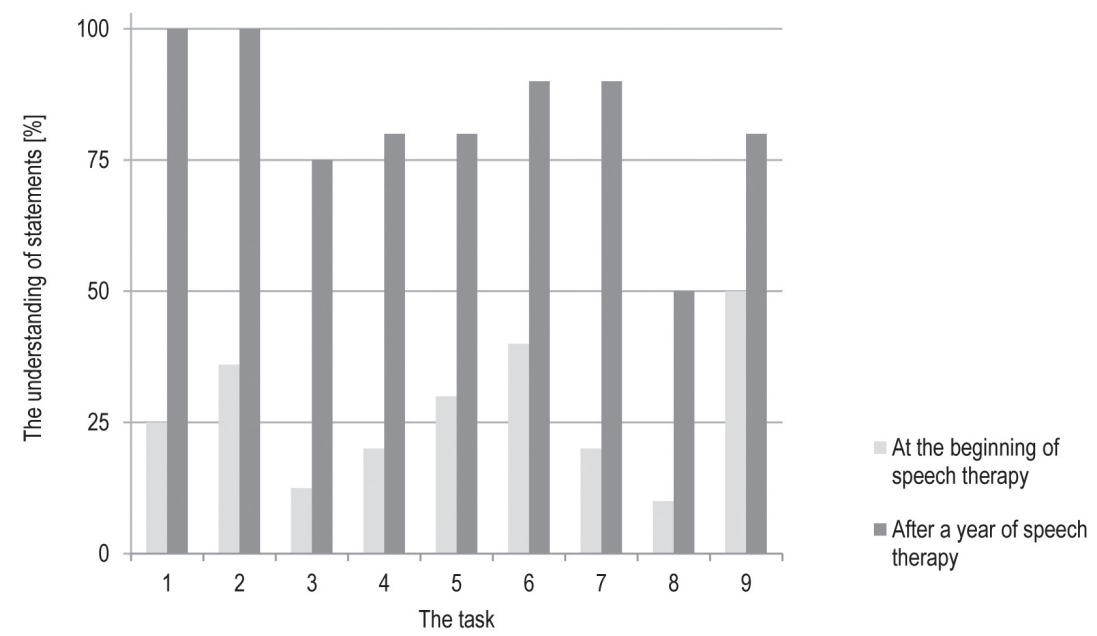

CHART 1. The dynamics of recovery from speech understanding disorders in the patient with semantic aphasia.

The numbers refer to the level of understanding of statements in particular tasks, concerning the following categories: 1) pragmatic function of statements; 2) texts with literal meaning; 3) texts with metaphorical meaning; 4) structures with passive voice; 5) sentence with syntactic inversion; 6) sentences with double negatives; 7) case governments; 8) comparative structures; 9) prepositional phrases.

Source: Own study. 
The results presented above, based on the author's experimental and clinical trials concerning the understanding of both longer statements and shorter linguistic structures with different levels of grammatical complexity, indicate a significant dynamics of the disappearance of disorders in the field of understanding in the examined patient. Patients with semantic aphasia in whom the simultaneous synthesis is disturbed, i.e. the ability to simultaneously analyse linguistic information in terms of logic, grammar, and form, have the greatest problems with grammatically complex forms of expression, which is confirmed by the case study presented in the article. After a year of the intensive speech therapy, in spite of a significant decrease in speech reception deficits, the patient still has difficulties (yet, to a much lesser degree) in understanding structures with the highest level of complexity, especially comparative structures, case governments, sentences with syntactic inversion or prepositional phrases with extensive context. The greatest progress can be seen in the understanding of the meaning of longer spoken statements, both dialogue texts (the understanding of pragmatic functions- informational, action, modal and emotional) and monologues (with a literal and metaphorical meaning; the assessment was based on four levels of text comprehension - global, selective, detailed, and interactive).

\section{Conclusions}

The progression of speech therapy in this case results from the organic factors (a relatively small area of brain damage), as well as the circumstances of the patient's position (an excellent home care and regular speech therapy). Moreover, it is also influenced by such social factors as the age of the patient, the higher technical education, friendly environment in which he lives, and the patient's great motivation, diligence, and determination in overcoming his limitations; finally, a great support of his family and their commitment also contribute to the results.

The dynamic changes in the picture of disorders, the disappearance of aphasic symptoms, good clinical condition, increasing life activity of the patient and his great motivation are the basis for making positive forecasts.

The topic presented in the article comprises a broader scope of research conducted by the author of this article, which encompasses the assessment of the activities of understanding spoken and written statements by people who are suffering from aphasia, as a result of focal brain damage within the speech area (in right-handed people - usually in the middle of the left hemisphere). The choice of topic depends on both cognitive and social needs. In the field of speech therapy research, the proposed issue has not been scrutinised so far. Aphasia, as a set of 
symptoms of language disorders, is a phenomenon described in various scientific disciplines; however, most researches focus on the process of transmitting speech. The publications on the subject lack the analysis of specific disorders of understanding spoken and written statements in case of aphasia.

The speech therapy practice shows that limitations in the perception of statements affect not only patients with sensory aphasia, as it is commonly believed, but also those diagnosed with motor aphasia. Such conclusions, in turn, indicate the need to conduct research in the field of comprehension in people with both sensory and motor aphasia, and, therefore, the need for a new description of individual types of aphasia.

It should also be remembered that the assessment of understanding is one of the basic goals of speech therapy diagnosis, and in case of finding disorders in this activity, its improvement becomes the primary objective of speech therapy. Therefore, I hope that the results of the research undertaken will contribute to deepening the knowledge about the state of understanding statements in people with aphasia, and will also become a valuable guide for speech therapists and neurological speech therapists in their work with patients in order to help them to overcome their limitations, blocking the access to words.

\section{References}

Bartmiński, J., \& Niebrzegowska-Bartmińska, S. (2009). Tekstologia. Warszawa: Wydawnictwo Naukowe PWN.

BĄK, P. (2010). Gramatyka języka polskiego. Warszawa: Wiedza Powszechna.

BocheneK, A., \& Reicher, M. (1981). Anatomia człowieka. T. IV: Układ nerwowy ośrodkowy. Warszawa: Wydawnictwo Lekarskie PZWL.

Boniecka, B. (2000). Struktura i funkcje pytań. Lublin: Wydawnictwo Uniwersytetu Marii Curie-Skłodowskiej.

Chodkiewicz, H. (1986). O sprawności czytania w nauczaniu języka obcego. Warszawa: Wydawnictwa Szkolne i Pedagogiczne.

Drabik, L., \& Sobol, E. (2007). Słownik języka polskiego. Warszawa: Wydawnictwo Naukowe PWN.

GoŁąB, B. (2004). Anatomia czynnościowa ośrodkowego układu nerwowego. Warszawa: Wydawnictwo Lekarskie PZWL.

Gra BIAS, S. (2019). Język w zachowaniach społecznych. Podstawy socjolingwistyki i logopedii. Lublin: Wydawnictwo Uniwersytetu Marii Curie-Skłodowskiej.

Grabias, S. (2007). Język, poznanie, interakcja. In: T. Woźniak, \& A. DomagaŁa (eds.), Język, interakcja, zaburzenia mowy. Metodologia badań (pp. 355-377). Lublin: Wydawnictwo Uniwersytetu Marii Curie-Skłodowskiej (Mowa. Teoria - Praktyka. T. 2).

Grabias, S. (1997). Mowa i jej zaburzenia. Lublin: Wydawnictwo Uniwersytetu Marii Curie-Skłodowskiej. 
Grabias, S. (2012). Teoria zaburzeń mowy. Perspektywy badań, typologie zaburzeń, procedury postępowania logopedycznego. In: S. Grabias, \& Z.M. Kurkowski (eds.), Logopedia. Teoria zaburzeń mowy (pp. 15-72). Lublin: Wydawnictwo Uniwersytetu Marii Curie-Skłodowskiej.

KąDzielawa, D. (1983). Czynność rozumienia mowy. Analiza neuropsychologiczna. Wrocław: Ossolineum.

Konorski, J. (1969). Integracyjna działalność mózgu. Warszawa: PWN.

Łuria, A.R. (1976). Podstawy neuropsychologii. Trans. D. KąDZielawa. Warszawa: PZWL.

Maruszewski, M. (1966). Afazja. Zagadnienia teorii i terapii. Warszawa: PWN.

Maruszewski, M. (1970). Mowa a mózg. Zagadnienia neuropsychologiczne. Warszawa: PWN.

Panasiuk, J. (2012). Diagnoza logopedyczna w przebiegu chorób neurologicznych u osób dorosłych. In: E. Czaplewska, \& S. Milewski (eds.), Diagnoza logopedyczna, Podręcznik akademicki (pp. 263-324). Gdańsk: Harmonia Universalis.

PANASIUK, J. (2013). Afazja a interakcja. TEKST - metaTEKST - konTESKT. Lublin: Wydawnictwo Uniwersytetu Marii Curie-Skłodowskiej.

Panasiuk, J. (2015). Standard postępowania logopedycznego w afazji. In: S. Grabias, J. Panasiuk, \& T. WoźNiaK (eds.), Logopedia. Standardy postępowania logopedycznego (pp. 869-916). Lublin: Wydawnictwo Uniwersytetu Marii Curie-Skłodowskiej.

Panasiuk, J., \& Woźniak, T. (2002). Pojęcie tekstu a zaburzenia mowy. In: S. Grabias (ed.), Zaburzenia mowy (pp. 108-132). Lublin: Wydawnictwo Uniwersytetu Marii Curie-Skłodowskiej (Mowa. Teoria - Praktyka. T. 1).

Polkowska, A. (1993). Rozumienie tekstu. In: I. Kurcz (ed.), Psychologia a semiotyka. Pojęcia i zagadnienia (pp. 266-267). Warszawa: Zakład Semiotyki Logicznej Uniwersytetu Warszawskiego „Znak. Język. Rzeczywistość”.

Prusiński, A. (1980). Podstawy neurologii klinicznej. Warszawa: PZWL.

Seretny, A., \& Lipińska, E. (2005). ABC metodyki nauczania języka polskiego jako obcego. Kraków: Universitas.

Stanosz, B. (2005). Wprowadzenie do logiki formalnej. Podręcznik dla humanistów. Warszawa: Wydawnictwo Naukowe PWN.

Walsh, K. (1998). Neuropsychologia kliniczna. Trans. B. Mroziak. Warszawa: Wydawnictwo Naukowe PWN.

WojciechowsKa, J. (2014). Metodologiczne podstawy badań nad rozumieniem w pragnozji. Forum Logopedyczne, 22, 35-44.

Wojciechowska, J. (2015). Ocena rozumienia tekstu w praktyce logopedycznej. Logopedia Silesiana, 4, 304-318. 


\title{
Kamila Bigos
}

Studia Doktoranckie, Wydział Humanistyczny,

\section{Dynamika ustępowania zaburzeń afatycznych u chorego po udarze mózgu}

\section{The dynamics of the regression of aphasic disorders in a stroke patient}

\begin{abstract}
Aвsтract: The most common diseases causing language difficulties of aphasia type include cerebral vascular diseases, including ischaemic strokes. Speech disorders resulting from brain damage are usually dynamic. The clinical picture, and further on, the effective diagnosis and speech therapy of a patient after a neurological incident, is thus greatly influenced both by the circumstances in which the patient found himself and the time factor. The paper presents the dynamics of aphasic disorders in a patient after ischaemic stroke within the left hemisphere. The aim is to draw attention to the changes in the image of aphasic disorders in a 63-year-old man after a neurological incident in which semantic aphasia was diagnosed, which is the evidence of differences in the occurrence of symptoms (including aphasic disorders) in the patient immediately after the stroke and over a dozen months after the incident, after an of intensive speech therapy.
\end{abstract}

KeYwORDS: neurological diseases, stroke, semantic aphasia

STRESZCZeniE: Do najczęstszych jednostek chorobowych powodujących trudności językowe o typie afazji należą choroby naczyniowe mózgu, a wśród nich udary niedokrwienne. Zaburzenia mowy wynikające z uszkodzeń mózgu mają zazwyczaj charakter dynamiczny. Duży wpływ na obraz kliniczny, a dalej - skuteczną diagnozę i terapię logopedyczną pacjenta po przebytym incydencie neurologicznym, mają zatem okoliczności, w jakich znalazł się chory, a także czynnik czasu. W artykule przedstawiono dynamikę ustępowania zaburzeń afatycznych u chorego po udarze niedokrwiennym w obrębie lewej półkuli mózgu. Celem jest zwrócenie uwagi na zmiany w obrazie zaburzeń u 63-letniego mężczyzny po przebytym incydencie neurologicznym, u którego zdiagnozowano afazję semantyczną. Stwierdzono różnice w występowaniu objawów (w tym zaburzeń afatycznych) u pacjenta bezpośrednio po udarze oraz po kilkunastu miesiącach od zachorowania, po intensywnej terapii logopedycznej.

SŁOWA KLUCZOWE: choroby neurologiczne, udar mózgu, afazja semantyczna 
Mowa ${ }^{1}$, jako najbardziej złożona czynność człowieka, jest wynikiem prawidłowej pracy całego układu nerwowego², a szczególnie mózgu, który jest jego najważniejszym elementem. Mózg pełni określone funkcje, które przypisuje się kolejno czterem płatom w obrębie każdej z półkul: 1) czołowemu - kontrola zachowania, planowanie, kontrola ruchów, 2) ciemieniowemu - odbiór wrażeń czuciowych, 3) skroniowemu - rozpoznawanie bodźców akustycznych i 4) potylicznemu percepcja bodźców wzrokowych (Panasiuk, 2013, s. 39-42).

Przyjmuje się, że choć czynności mowy są wynikiem normatywnego współdziałania całej kory mózgowej, w obrębie lewej półkuli mózgu można wyróżnić tzw. obszar mowy, który obejmuje: tylno-dolną część płata czołowego, tylną część górnego i środkowego zakrętu skroniowego, okolicę styku skroniowo-ciemieniowo-potylicznego oraz przyśrodkową część lewego płata czołowego (Prusiński, 1980, s. 71).

Z obserwacji wynika, że udział półkul w czynnościach mowy jest nierównomierny - jedna z nich zawsze jest dominująca względem drugiej, u osób praworęcznych zwykle jest to lewa półkula mózgu (Walsh, 1998, s. 354-411). Zasada lateralizacji funkcji, zgodnie z którą lewa półkula staje się dominująca względem prawej, niezwiązanej z pracą prawej ręki i mowy, jest zasadą funkcjonalnej organizacji kory mózgowej człowieka (Łuria, 1976, s. 117). Wiadomo również, że dominująca półkula mózgu (zazwyczaj lewa) pełni istotną funkcję nie tylko w mózgowej organizacji mowy, ale i w wypadku wszystkich wyższych czynności psychicznych z nią związanych (jak spostrzeganie kategorialne, pamięć werbalna, logiczne myślenie), podczas gdy półkula podległa (zwykle prawa) uczestniczy w ich przebiegu w znacznie mniejszym stopniu (Łuria, 1976, s. 117).

W wyniku ogniskowych uszkodzeń mózgu w obrębie obszaru mowy (zwykle środkowej części lewej półkuli u osób praworęcznych) występuje afazja. W drugiej połowie XX wieku Mariusz Maruszewski (1966) zdefiniował ją jako: „spowodowane organicznym uszkodzeniem odpowiednich struktur mózgowych częściowe lub całkowite zaburzenie mechanizmów programujących czynności mowy u człowieka, który już uprzednio opanował te czynności” (s. 98). Z perspektywy logopedycznej ujęcie to najpełniej oddaje istotę tej jednostki zaburzeń mowy, ponieważ szeroko i precyzyjnie obejmuje wszystkie zaburzenia mowy o podłożu neurogennym, a także pozwala na ich różnicowanie, z wyraźnym zaznaczeniem,

${ }^{1}$ Przyjmuję, że mowa jest to „zespół czynności, jakie przy udziale języka wykonuje człowiek, poznając świat i przekazując jego interpretację innym uczestnikom życia społecznego" (Grabias, 2012, s. 15).

${ }^{2}$ Układ nerwowy człowieka dzieli się na: I) ośrodkowy układ nerwowy, OUN, na który składa się: 1) rdzeń kręgowy, 2) mózgowie, które stanowią: a) pień mózgu (rdzeń przedłużony, most, śródmózgowie), b) móżdżek oraz c) mózg (międzymózgowie, kresomózgowie), oraz II) obwodowy układ nerwowy, czyli zwoje oraz nerwy, które odpowiadają za przekazywanie informacji z OUN do poszczególnych narządów (Gołąb, 2004). 
że afazja nie jest dezintegracją systemu językowego, jak traktowali ją dotąd lingwiści, ale zaburzeniem czynności rozumienia i mówienia.

\section{Anatomiczne i funkcjonalne podstawy afazji semantycznej}

Afazja to zaburzenie mowy wynikające z uszkodzenia kory mózgu. Aleksander R. Łuria wyróżnia trzy grupy pól korowych: 1) pola pierwszorzędowe (projekcyjne, pierwotne), które odpowiadają za docieranie informacji do centrum, a ich uszkodzenie implikuje zaburzenia: słyszenia (płat skroniowy), widzenia (płat potyliczny), czucia (płat ciemieniowy); 2) pola drugorzędowe (asocjacyjne, kojarzeniowe, wtórne), których zadaniem jest analiza i synteza wrażeń słuchowych, wzrokowych i czuciowych docierających z pól pierwszorzędowych, co warunkuje rozpoznawanie tych sygnałów przez mózg, a uszkodzenie prowadzi do różnego typu agnozji; 3) pola trzeciorzędowe (właściwe pola asocjacyjne), których rola polega na integracji informacji przesyłanych z pół drugorzędowych; zlokalizowane na styku trzech analizatorów: słuchowego w płacie skroniowym, wzrokowego w płacie potylicznym i somestetycznego w płacie ciemieniowym (okolica TPO, temporo-parieto-occipitalis) oraz w okolicy przedczołowej (Łuria, 1976, s. 17-41).

Autor podkreśla, że nadrzędną zasadą budowy kory mózgowej jest hierarchiczna organizacja okolic korowych, co oznacza odpowiedzialność kolejnych pól za realizację coraz bardziej złożonej syntezy docierających informacji, a relacje między kolejnymi okolicami są różne w okresie ontogenezy. U małego dziecka bowiem warunkiem powstania okolic drugorzędowych są prawidłowo wykształcone okolice pierwszorzędowe i podobnie - do prawidłowego kształtowania się okolic trzeciorzędowych konieczna jest normatywna budowa okolic drugorzędowych (Łuria, 1976, s. 114). Warto wspomnieć również, że okolice trzeciorzędowe kształtują się wyłącznie u człowieka i dojrzewają najpóźniej w procesie ontogenezy tylnej części mózgu; uważa się, że finalizacja ich rozwoju i początek normatywnego funkcjonowania następują dopiero w 7. roku życia człowieka (Łuria, 1976, s. 182).

$\mathrm{W}$ niniejszym artykule został przedstawiony opis zaburzeń u pacjenta $\mathrm{z}$ afazją semantyczną będącą następstwem uszkodzenia pól trzeciorzędowych zlokalizowanych w okolicy styku TPO, których zasadnicza funkcja sprowadza się do integracji bodźców dochodzących z różnych analizatorów. Poznawcza działalność człowieka opiera się na współpracy całego systemu kory mózgu, odpowiedzialne są za nią okolice nakładania się korowych części tychże analizatorów. Łuria wskazuje, że znaczna część zlokalizowanych tu neuronów ma charakter polimodalny i reaguje na kompleksowe cechy środowiska (takie jak: lokalizacja przestrzenna 
czy liczba elementów w zbiorze), na które nie odpowiadają komórki nerwowe tworzące okolice pierwszo- i drugorzędowe. Za najważniejsze funkcje właściwych pół asocjacyjnych przyjmuje się przestrzenną organizację pobudzeń oraz przekształcanie kolejno napływających sygnałów (sukcesywnych) w działające jednoczesne grupy (symultatywne), z czego wynika syntetyczny charakter spostrzegania. Rola trzeciorzędowych okolic tylnej części mózgu nie sprowadza się jednak wyłącznie do prawidłowej syntezy bezpośrednio odbieranych informacji. Ich funkcją jest również transformacja z poziomu bezpośredniej naocznej syntezy do poziomu procesów symbolicznych, operowania znaczeniem słów, złożonymi konstrukcjami gramatycznymi i logicznymi, systemami liczb i relacjami abstrakcyjnymi. Łuria trzeciorzędowe okolice tylnych części kory mózgowej nazywa aparatami, które są konieczne do przekształcania postrzegania bezpośredniego, zmysłowego w myślenie abstrakcyjne regulowane przez schematy wewnętrzne oraz do utrzymywania w pamięci zorganizowanego doświadczenia (Łuria, 1976, s. 182).

W przypadku uszkodzenia trzeciorzędowych okolic kory mózgu, które są anatomicznym podłożem najwyższych form poznawczej działalności człowieka, znaczenia nabiera zasada lateralizacji wyższych czynności psychicznych. Obszary te są bowiem podstawą funkcjonalnej organizacji informacji, jakie docierają do kory mózgowej człowieka za pomocą mowy. Funkcja pól trzeciorzędowych u dorosłego człowieka staje się zatem znacząco różna w przypadku lewej półkuli mózgu (Łuria, 1976, s. 182).

\section{Symptomy ogniskowych uszkodzeń mózgu w okolicy skroniowo-ciemieniowo-potylicznej}

Ogniskowe uszkodzenia mózgu w okolicach trzeciorzędowych pól kory mózgu objawiają się zaburzeniami mowy w postaci afazji semantycznej ${ }^{3}$, charakteryzującej się trudnościami w rozumieniu złożonych gramatycznie form wypowiedzi (np. wyrażeń przyimkowych, związków rządu, zdań z inwersją składniową czy konstrukcji w stronie biernej). Ten typ afazji warunkowany jest zaburzeniami syntezy symultatywnej - zdolności jednoczesnej analizy napływających informacji językowych pod względem logiczno-gramatyczno-semantycznym (Panasiuk, 2013, s. 124).

Chorzy mają trudności w rozumieniu odebranej informacji (np. wzrokowej, słuchowej) jako całości, a specyficzną cechą uszkodzenia okolicy TPO jest utra-

${ }^{3}$ W literaturze przedmiotu na określenie tego typu afazji stosowane są również terminy afazja amnestyczna, afazja nominalna. 
ta umiejętności zmysłowej syntezy przestrzennej - zaburzenia orientacji przestrzennej, co w praktyce oznacza, że pacjenci mają trudności w odnalezieniu się w otoczeniu, nie są w stanie prawidłowo odczytać i zinterpretować mapy czy też samodzielnie utworzyć planu nawet dobrze znanych im miejsc. W przypadku głębszych zaburzeń występują także problemy z lokalizacją przedmiotów w przestrzeni, próbą naśladowania układu ułożenia rąk demonstrowanego przez inną osobę czy też zbudowania dowolnej figury z podanych elementów, co określane jest mianem apraksji konstrukcyjnej. Szczególnie wyraźne trudności dotyczą graficznego przedstawiania liter, co nie wynika z zaburzeń analizy fonemowej słowa, ale jest rezultatem niepoprawnej analizy przestrzennej linii tworzących litery, a skutkuje zaburzeniami czynności pisania (Łuria, 1976, s. 181-183).

Kolejnym objawem uszkodzenia okolicy styku płatów skroniowego, ciemieniowego i potylicznego w obrębie lewej półkuli mózgu są trudności z syntezą symboliczną (quasi-przestrzenną), która dotyczy problemów z analizą stosunków symbolicznych. Chorzy dobrze rozumieją zwroty języka potocznego, mają jednak trudności ze złożonymi strukturami logiczno-gramatycznymi (jak np. złożone struktury syntaktyczne, stosunki abstrakcyjne, tj. związki rządu, konstrukcje przyimkowe i czasowe, strona bierna, inwersja składniowa). Zaburzenia syntezy quasi-przestrzennej wyrażają się u tej grupy chorych także przez trudności $\mathrm{w}$ dokonywaniu operacji matematycznych. Zaburzenie syntezy symultatywnej na poziomie mnestycznym i werbalnym implikuje istotne problemy w sferze operacji poznawczych, konkretno-obrazowych procesów myślowych. Pacjenci mają kłopoty nie tylko z formułowaniem myśli, ale i z realizacją czynności intelektualnych przy rozumieniu ogólnego sensu zdania występują spore trudności z rozpoznawaniem form gramatycznych czy struktur porównawczych (Łuria, 1976, s. 181-183).

Trzecim typem dysfunkcji powstających w wyniku uszkodzenia okolicy TPO w obrębie lewej półkuli mózgu są zaburzenia procesów pamięci werbalnej, które objawiają się jako trudności w znajdowaniu nazw; badania wskazują, że największe zaburzenia dotyczą nazw przedmiotów, następnie - cech czynności i samych czynności. Pacjenci zazwyczaj wymieniają słowa podobne pod względem semantycznym, morfologicznym lub fonetycznym, co manifestuje się w postaci parafazji werbalnych i głoskowych (Łuria, 1976, s. 181-183).

\section{Egzemplifikacja}

Zaprezentowane badania dotyczą 63-letniego mężczyzny, który w lutym 2019 roku został przyjęty na Oddział Udarowy i Wczesnej Rehabilitacji Poudarowej Samodzielnego Publicznego Szpitala Klinicznego nr 4 w Lublinie z powo- 
du udaru niedokrwiennego w obrębie lewej półkuli mózgu (płat ciemieniowy). U mężczyzny stwierdzono miażdżycę tętnic domózgowych i niedrożność lewej tętnicy szyjnej wewnętrznej. Pacjent był leczony wcześniej z powodu cukrzycy typu 2 oraz nadciśnienia tętniczego.

Po dwóch miesiącach od wystąpienia udaru mężczyzna zgłosił się do Pracowni Logopedycznej działającej w Zakładzie Logopedii i Językoznawstwa Stosowanego Uniwersytetu Marii Curie-Skłodowskiej w Lublinie. W Poradni zdiagnozowano u mężczyzny afazję semantyczną i poddał się on zaproponowanej terapii mowy.

Pacjent posiada wyższe wykształcenie techniczne - tytuł magistra inżyniera budownictwa Politechniki Lubelskiej. Przez wiele lat pracował jako kierownik budowy. Od czasu incydentu neurologicznego nie podejmuje pracy zawodowej. Często, wspólnie z rodziną, wyjeżdża na działkę za miastem, gdzie zajmuje się ogrodem i wykańczaniem domku letniskowego. Dużo czasu spędza także z wnukami, co jest dla niego dodatkową aktywnością i motywacją w pokonywaniu codziennych trudności i barier, jakie niosą ograniczenia w sferze językowej i komunikacyjnej.

W celu zaprezentowania zmian $\mathrm{w}$ obrazie zaburzeń afatycznych u chorego z afazją semantyczną zestawiono wyniki badań dotyczących rozumienia wypowiedzi mówionych i przeprowadzonych na podstawie prób eksperymentalno-klinicznych $\mathrm{w}$ chwili przystąpienia przez mężczyznę do terapii oraz po roku systematycznej, intensywnej terapii logopedycznej.

\section{Zadanie 1. Proszę posłuchać czytanego tekstu, a następnie odpowiedzieć na pytania}

\section{TEKST 1}

- Dzień dobry.

- Dzień dobry. Panie Wojtku, co panu dolega?

- Mam wysoką temperaturę, boli mnie gardło i głowa.

- Yhym, a kaszel, katar?

- Nie kaszlę, ale mam katar.

- Dobrze, w takim razie proszę się rozebrać. Osłucham pana, a później zaglądnę do gardła.

- I co?

- Rzeczywiście, gardło jak żywy ogień! To angina. Gdzie się pan tak załatwił? W pracy?

- Nie, na pewno nie w pracy. Nie wiem... Być może złapałem coś na urodzinach córki. Wie pan, było dużo dzieci.

- To prawdopodobne. Przepiszę panu antybiotyk, proszę go brać przez siedem dni. Czy potrzebuje pan zwolnienie?

- Nie, od miesiąca nie pracuję. 
K. Bigos: Dynamika ustępowania zaburzeń afatycznych u chorego po udarze mózgu

TABELA 1. Rozumienie struktur językowych w tekstach mówionych - funkcje pragmatyczne wypowiedzi

\begin{tabular}{|c|c|c|c|}
\hline \multirow{2}{*}{ Lp. } & \multirow{2}{*}{ Pytanie } & \multicolumn{2}{|c|}{ Odpowiedź } \\
\hline & & na początku terapii & po roku terapii \\
\hline 1 & $\begin{array}{l}\text { Gdzie odbywa się roz- } \\
\text { mowa? }\end{array}$ & $\begin{array}{l}\text { No, właśnie nie wiem... No, } \\
\text { ma temperaturę, później się } \\
\text { rozebrał ten człowiek... Jeszcze } \\
\text { mam mówić? }\end{array}$ & U lekarza. \\
\hline 2 & $\begin{array}{l}\text { Jakie objawy zgłasza } \\
\text { pacjent? }\end{array}$ & $\begin{array}{l}\text { No, jest chory człowiek, praw- } \\
\text { da... i przyszedł do lekarza, no } \\
\text { i lekarz go bada. Aha! Dolegało } \\
\text { mu gardło i było, że lekarz go } \\
\text { ustuchat. }\end{array}$ & $\begin{array}{l}\text { Zaczerwienione gardło, ale to } \\
\text { lekarz mówił. [B: A pacjent?] } \\
\text { Bolała go głowa, gardło no i miał } \\
\text { goraczkę. [B: A, czy kasłał?] Nie, } \\
\text { ale miał katar. O, właśnie, pamię- } \\
\text { tam! }\end{array}$ \\
\hline 3 & $\begin{array}{l}\text { Czy pacjent potrzebu- } \\
\text { je zwolnienie? }\end{array}$ & $\begin{array}{l}\text { Oj, nie pamiętam... [zasta- } \\
\text { nawia się] Przez ileś tam dni } \\
\text { chyba. }\end{array}$ & Nie potrzebuje, bo już nie pracuje. \\
\hline 4 & $\begin{array}{l}\text { Jakie działania podjął } \\
\text { lekarz? }\end{array}$ & $\begin{array}{l}\text { No, przyszedł ten człowiek } \\
\text { i mówi, że jest chory. }\end{array}$ & $\begin{array}{l}\text { Pewnie kazał mu brać jakieś } \\
\text { pigułki... Ten, no... antybiotyk! } \\
\text { [B: A wcześniej?] No, ostuchat } \\
\text { i to gardło mu sprawdzit. }\end{array}$ \\
\hline 5 & $\begin{array}{l}\text { Jakie zalecenia otrzy- } \\
\text { mał pacjent? }\end{array}$ & Antybiotyk? & No, to ten antybiotyk mu dat. \\
\hline 6 & $\begin{array}{l}\text { Czy pacjent rozchoro- } \\
\text { wał się w pracy? }\end{array}$ & $\begin{array}{l}\text { W pracy? Nie wiem, nie pamię- } \\
\text { tam... }\end{array}$ & $\begin{array}{l}\text { Nie, była impreza u dzieci i praw- } \\
\text { dopodobnie się ten ojciec zarazit. }\end{array}$ \\
\hline 7 & $\begin{array}{l}\text { Czy pacjent jest } \\
\text { pewien, gdzie się za- } \\
\text { raził anginą? }\end{array}$ & No, to pewnie w tej pracy, tak? & $\begin{array}{l}\text { Znaczy, no pewien... No tak na } \\
\text { sto procent nie, ale pewnie na tej } \\
\text { imprezie właśnie. }\end{array}$ \\
\hline 8 & $\begin{array}{l}\text { Jak czuje się pacjent? } \\
\text { Jakie emocje mogą } \\
\text { mu towarzyszyć? }\end{array}$ & $\begin{array}{l}\text { No, źle się czuje chyba. Chory } \\
\text { jest. }\end{array}$ & $\begin{array}{l}\text { Ale konkretnie? Ten pacjent? No } \\
\text { kiepsko się czuje, jakieś tam właś- } \\
\text { nie... bóle głowy, gardła... } \\
\text { [B: Czyli, jakie emocje mu towa- } \\
\text { rzyszą, jaki jest?] Taki ochlapły... } \\
\text { pewnie umęczony. }\end{array}$ \\
\hline
\end{tabular}

ŹRóDŁo: Opracowanie własne.

W tabeli 1 przedstawiono wyniki badania rozumienia przez pacjenta funkcji pragmatycznych wypowiedzi ${ }^{4}$, którego celem była ocena rozpoznania intencji

${ }^{4}$ Ocenie poddano rozumienie funkcji pragmatycznych wypowiedzi, według typologii zaproponowanej przez Stanisława Grabiasa $(1997,2007,2019)$, który wyróżnia: 1) funkcję informacyjną, 2) funkcję działania, 3) funkcję modalną, 4) funkcję informacyjną. 
przekazywanych przez nadawcę w podanej rozmowie (tekst 1). Badanie przeprowadzone w chwili rozpoczęcia terapii logopedycznej wskazuje na znaczne zaburzenia w zakresie omawianej czynności. Pacjent udzielał zazwyczaj nieadekwatnych odpowiedzi. Rozumiał ogólny sens wypowiedzi, jednakże nie zawsze odnosił się do konkretnego pytania. W dwóch przypadkach badany w ogóle nie zrozumiał zadanego mu pytania $(1,4)$ i udzielił niepoprawnych odpowiedzi. Zdarzało się także, że badany rozumiał zadane mu pytanie, lecz nie udzielał prawidłowej odpowiedzi. Poprawnie odpowiedział tylko na jedno pytanie (5), jednakże nie był pewien swojej odpowiedzi. Wyniki uzyskane podczas badania powtórzonego rok później jednoznacznie wskazują na znaczną poprawę w zakresie rozumienia intencji nadawcy w przedstawionym dialogu. Pacjent udzielił prawidłowej odpowiedzi na każde z zadanych mu pytań; zdarzało się, że potrzebował pytań dodatkowych, na które pewnie odpowiadał. Badany był pewien swoich odpowiedzi, a jego wypowiedzi były zdecydowanie dłuższe i bogatsze w treści.

\title{
Zadanie 2. Proszę posłuchać czytanego tekstu, a następnie odpowiedzieć na pytania
}

\section{TeKsT 2}

\author{
Naukowe Koło Teatrologów \\ Uniwersytetu Warszawskiego \\ ma zaszczyt zaprosić \\ Studentów Wydziału Polonistyki \\ na spektakl pt. „Syzyfowe prace”, \\ który odbędzie się 15 maja 2019 r. o godz. 18.00 \\ w Auli Głównej Wydziału Polonistyki UW, \\ przy ul. Krakowskie Przedmieście 26/28. \\ Serdecznie zapraszamy!
}

W kolejnej próbie ocenie poddano rozumienie tekstu mówionego o znaczeniu dosłownym ${ }^{5}$ (tekst 2 , tabela 2 ). Wyniki wskazują, że pacjent na początku podjętych oddziaływań terapeutycznych rozumiał ogólny sens tekstu, jednak miał trudności z udzieleniem odpowiedzi na zadawane mu pytania - jeśli udało mu się udzielić prawidłowych odpowiedzi (pytania 2, 5), to nie był ich pewien. Zazwyczaj odpowiadał nieadekwatnie lub nie udzielał odpowiedzi wcale. Po roku intensywnej

${ }^{5}$ Rozumienie znaczenia tekstów oceniono w odniesieniu do czterech poziomów rozumienia wypowiedzi, takich jak: 1) poziom globalny, wiążący się z rozumieniem tekstu jako całości, 2) poziom selektywny, odnoszący się do zawartości treściowej tekstu oraz umiejętności dokonywania selekcji w celu wydobycia konkretnych informacji, 3) poziom szczegółowy, dotyczący dążenia do ujawnienia sensu tekstu poprzez analizę znaczenia konkretnych jednostek leksykalnych, umiejętności wyjaśniania metafor i wyciągania wniosków, oraz 4) poziom interakcyjny, odnoszący się do sytuacji komunikacyjnej, w której osadzony jest tekst (Wojciechowska, 2015). 
K. Bigos: Dynamika ustępowania zaburzeń afatycznych u chorego po udarze mózgu

TABela 2. Rozumienie struktur językowych w tekstach mówionych - tekst o znaczeniu dosłownym

\begin{tabular}{|c|c|c|c|}
\hline \multirow{2}{*}{ Lp. } & \multirow{2}{*}{ Pytanie } & \multicolumn{2}{|c|}{ Odpowiedź } \\
\hline & & na początku terapii & po roku terapii \\
\hline 1 & Jaki to rodzaj tekstu? & $\begin{array}{l}\text { No, nie wiem... ale, o co Pani } \\
\text { pyta? [B powtórzył pytanie] } \\
\text { Rodzaj tekstu... [zastanawia } \\
\text { się] No, jest jakaś informacja, } \\
\dot{z} \text { e będzie się coś działo i maja } \\
\text { przyjść na to. }\end{array}$ & To jest zaproszenie. \\
\hline 2 & $\begin{array}{l}\text { O czym jest tekst? } \\
\text { Czego dotyczy? }\end{array}$ & $\begin{array}{l}\text { No, że jest jakiś tam... kurcze, } \\
\text { no nie wiem... coś się będzie } \\
\text { działo, jakieś przedstawienie, } \\
\text { tak? Ale nie pamiętam, jakie. }\end{array}$ & $\begin{array}{l}\text { Koło naukowe zaprosiło, ale właś- } \\
\text { nie nie wiem... na jakiś spektakl, } \\
\text { chyba „Syzyfowe prace”. }\end{array}$ \\
\hline 3 & $\begin{array}{l}\text { W jakim miejscu } \\
\text { odbędzie się przedsta- } \\
\text { wienie? }\end{array}$ & $\begin{array}{l}\text { O-o! Pojęcia nie mam... nie } \\
\text { pamiętam. [B: W teatrze czy } \\
\text { w auli uniwersyteckiej?] Tam } \\
\text { było cośo tym uniwersytecie... }\end{array}$ & $\begin{array}{l}\text { W auli jakiejś... chyba uniwersy- } \\
\text { teckiej. Na pewno w Warszawie. }\end{array}$ \\
\hline 4 & $\begin{array}{l}\text { Przy jakiej ulicy mie- } \\
\text { ści się Wydział Polo- } \\
\text { nistyki UW? }\end{array}$ & $\begin{array}{l}\text { [powtarza zdanie, długo się } \\
\text { zastanawia] Kurczę, nie słysza- } \\
\text { łem tego chyba... }\end{array}$ & $\begin{array}{l}\text { Wiem, że to było, ale kurczę, nie } \\
\text { pamiętam... [zastanawia się] ... } \\
\text { w Lublinie też jest, na Starym } \\
\text { Mieście. [B: Kra...] Krakowskie } \\
\text { Przedmieście, no pewnie, że tak! }\end{array}$ \\
\hline 5 & $\begin{array}{l}\text { Co oznacza sformu- } \\
\text { łowanie „syzyfowa } \\
\text { praca”? }\end{array}$ & $\begin{array}{l}\text { No, syzyfowa, jak mam to } \\
\text { wyttumaczyć? [zastanawia się] } \\
\text { Nie daje zadowolenia? }\end{array}$ & $\begin{array}{l}\text { Praca, która nie daje zadowolenia } \\
\text { i efektów. }\end{array}$ \\
\hline 6 & $\begin{array}{l}\text { Czy przedstawienie } \\
\text { będzie wystawiane } \\
\text { przez profesjonalnych } \\
\text { aktorów? }\end{array}$ & $\begin{array}{l}\text { Tak, będzie wystawiane przez } \\
\text { aktorów. }\end{array}$ & $\begin{array}{l}\text { Nie, bo to było jakieś koło teatral- } \\
\text { ne. [B: Czyli, kim są aktorzy?] No, } \\
\text { kim sa... pewnie studenci. }\end{array}$ \\
\hline 7 & $\begin{array}{l}\text { W jakim celu powstał } \\
\text { tekst? }\end{array}$ & $\begin{array}{l}\text { W jakim celu? A czy ja wiem... } \\
\text { No nie wiem, jak to powie- } \\
\text { dzieć, naprawdę. }\end{array}$ & $\begin{array}{l}\text { Żeby zachęcić do przyjścia na ten } \\
\text { spektakl. }\end{array}$ \\
\hline 8 & $\begin{array}{l}\text { Kto jest odbiorcą tek- } \\
\text { stu? }\end{array}$ & No, pewnie ten, co to pisat. & $\begin{array}{l}\text { No, do wszystkich studentów, któ- } \\
\text { rzy chcieliby przyjść na to przed- } \\
\text { stawienie. }\end{array}$ \\
\hline
\end{tabular}

ŹRóDŁo: Opracowanie własne.

pracy wyniki przedstawiają się zupełnie inaczej. Pacjent odpowiedział prawidłowo na wszystkie pytania. Czasem w celu uzyskania dokładniejszych informacji zadano badanemu pytanie dodatkowe lub udzielono nieznacznej podpowiedzi (pytania 4, 6), w wyniku czego mężczyzna odpowiadał poprawnie. Trudności pacjenta wiązały się bardziej z przypomnieniem sobie konkretnych informacji zawartych w tekście niż z ich zrozumieniem. 


\section{Zadanie 3. Proszę posłuchać czytanego tekstu, a następnie odpowiedzieć na pytania}

\section{TEKst 3}

„Czegóż płaczesz? - staremu mówił czyżyk młody -

Masz teraz lepsze w klatce niż w polu wygody”.

„Tyś w niej zrodzon - rzekł stary - przeto ci wybaczę;

Jam był wolny, dziś w klatce - i dlatego płaczę".

Ignacy Krasicki, Ptaszki w klatce

TABELA 3. Rozumienie struktur językowych w tekstach mówionych - tekst o znaczeniu metaforycznym

\begin{tabular}{|c|c|c|c|}
\hline \multirow{2}{*}{ Lp. } & \multirow{2}{*}{ Pytanie } & \multicolumn{2}{|c|}{ Odpowiedź } \\
\hline & & na początku terapii & po roku terapii \\
\hline 1 & Jaki to rodzaj tekstu? & O, Boże, no... jakieś ptaki były. & Bajka Krasickiego. \\
\hline 2 & $\begin{array}{l}\text { O czym jest tekst? } \\
\text { Czego dotyczy? }\end{array}$ & $\begin{array}{l}\text { Chodzi o to, że jest jakiś stary } \\
\text { i młody ptak. No i jeden jest } \\
\text { taki... załóżmy, że nie jest } \\
\text { wolny, no i co... tyle. }\end{array}$ & $\begin{array}{l}\text { Że jest sobie stary ptak, o, tak to } \\
\text { nazwijmy. I jest pewna kwestia taka, } \\
\dot{z} \text { je jest drugi ptaszek, który nigdy } \\
\text { nie byt na wolności i dlatego jest mu } \\
\text { ciężko zrozumieć, że ktoś, kto kiedyśs } \\
\text { był wolny, nagle nie jest wolny. }\end{array}$ \\
\hline 3 & $\begin{array}{l}\text { Jakie ptaki są bohate- } \\
\text { rami tekstu? }\end{array}$ & $\begin{array}{l}\text { No, szczerze mówiąc, to nie } \\
\text { pamiętam... }\end{array}$ & Czyżyki. \\
\hline 4 & $\begin{array}{l}\text { W jakim miejscu } \\
\text { znajdują się ptaki? }\end{array}$ & $\begin{array}{l}\text { Chodzi o to, że jeden z tych } \\
\text { ptaków, że czuje się... no załóż- } \\
\text { my, że nie czuje się dobrze. }\end{array}$ & W tej klatce są zamknięte. \\
\hline 5 & $\begin{array}{l}\text { Jakiego okresu w } \\
\text { historii Polski doty- } \\
\text { czy tekst? }\end{array}$ & $\begin{array}{l}\text { Polski? No właśnie nie, wiem, } \\
\text { jak to powiedzieć... Bo ten } \\
\text { jeden ptak jest samotny. }\end{array}$ & $\begin{array}{l}\text { No właśnie, to jest ciekawe... A to } \\
\text { było tam napisane? Jak } w \text { nie- } \\
\text { woli była Polska, ale jak to powie- } \\
\text { dzieć... [B: Kiedy Polska była } \\
\text { pod...] No, pod zaborami była. }\end{array}$ \\
\hline 6 & $\begin{array}{l}\text { Jaka nauka wypływa } \\
\text { z tekstu? }\end{array}$ & $\begin{array}{l}\text { Nauka? Jeden z tych ptaków, } \\
\text { załóżmy, że jest zadowolony, } \\
\text { ale nie jest wolny, tyle chyba. }\end{array}$ & $\begin{array}{l}\text { Nie bardzo wiem, jaka nauka może } \\
\text { wyplywać... [B: Już Pan trochę } \\
\text { powiedział, ale teraz w odniesie- } \\
\text { niu do zaborów] Nie, no, ja rozu- } \\
\text { miem tekst tej bajki, tylko teraz nie } \\
\text { wiem, jak to określić... Że tęsknili } \\
\text { za wolnością? }\end{array}$ \\
\hline 7 & $\begin{array}{l}\text { W jakim celu } \\
\text { powstał tekst? }\end{array}$ & $\begin{array}{l}\text { No, bo to jest ta przenośnia } \\
\text { taka, bo jeden ten ptak byt } \\
\text { przeniesiony, znaczy, ja źle to } \\
\text { tłumaczę, ale... [prosi o wgląd] }\end{array} \mid$ & $\begin{array}{l}\text { Żeby docenić wolność, ale ja wiem, } \\
\text { czy to o to chodzi? }\end{array}$ \\
\hline
\end{tabular}




\begin{tabular}{|c|l|l|l|} 
cd. & & $\begin{array}{l}\text { Nie pamiętam, jak to było } z \\
\text { tym wierszem, bo kiedyś... } \\
\text { Znaczy ja wiem, że on był tam } \\
\text { kiedyś. Ale ja nie bardzo to tłu- } \\
\text { maczę w tym momencie. }\end{array}$ & \\
\hline 8 & $\begin{array}{l}\text { Kto może być odbior- } \\
\text { cą tekstu? }\end{array}$ & $\begin{array}{l}\text { Odbiorca? Szczerze mówią, to } \\
\text { nie wiem, naprawdę. }\end{array}$ & Ci, co nie są wolni? \\
\hline
\end{tabular}

ŹróDŁo: Opracowanie własne.

Tabela 3 zawiera wyniki badania rozumienia tekstu mówionego o znaczeniu metaforycznym (tekst 3). Odpowiedzi zebrane na początku podjętej terapii wskazują, że pacjent nie rozumiał czytanego mu tekstu. Choć bardzo się starał, w pełni prawidłowo nie odpowiedział na żadne z zadanych mu pytań. Odbierał tekst dosłownie, rozpoznając jego znaczenie globalne, nie zauważał jednak jego znaczenia metaforycznego. Rok później obraz zaburzeń znacznie się zmienił dotyczyły one jedynie poziomu interakcyjnego i po części szczegółowego (w zakresie wyciągania wniosków). Badany na większość pytań odpowiedział prawidłowo, w sposób pewny i zdecydowany.

\section{Zadanie 4. Proszę posłuchać czytanych zdań i odpowiedzieć na pytania}

1. Jan został pochwalony przez Maćka.

2. Anna została obrażona przez Marię.

3. Janusz został poproszony przez Tomasza o pomoc.

4. Wojtek został zasmucony przez Olę.

5. Karol został wpisany przez Jacka na listę.

6. Kasia została odprowadzona przez Basię do przedszkola.

7. Tomek został zaproszony przez Wojtka.

8. Jaś został ukarany przez Waldka.

9. Adam został przedstawiony przez Olę rodzicom.

10. Kuba został wyśmiany przez Bartka.

TABELA 4. Rozumienie struktur językowych w tekstach mówionych - strona bierna

\begin{tabular}{|c|l|l|l|}
\hline \multirow{2}{*}{ Lp. } & \multicolumn{2}{|c|}{ Pytanie } & \multicolumn{2}{c|}{ Odpowiedź } \\
\cline { 2 - 4 } & \multicolumn{1}{|c|}{ na początku terapii } & \multicolumn{1}{c|}{ po roku terapii } \\
\hline 1 & $\begin{array}{l}\text { Kto otrzymał } \\
\text { pochwałę? }\end{array}$ & $\begin{array}{l}\text { Jeszcze raz? [powtarza zdanie] } \\
\text { No, to Maciek. }\end{array}$ & $\begin{array}{l}\text { [powtarza zdanie] No, czyli } \\
\text { Maciek? }\end{array}$ \\
\hline 2 & Kto jest obrażony? & $\begin{array}{l}\text { [powtarza zdanie kilkakrot- } \\
\text { nie] Anna? Ale zgaduję. }\end{array}$ & [powtarza zdanie] Anna. \\
\hline 3 & Kto prosił o pomoc? & $\begin{array}{l}\text { [powtarza zdanie] Momen- } \\
\text { cik... Janusz. }\end{array}$ & [powtarza zdanie] Tomek? \\
\hline
\end{tabular}


K. Bigos: Dynamika ustępowania zaburzeń afatycznych u chorego po udarze mózgu

cd. tabeli 4

\begin{tabular}{|c|l|l|l|}
\hline 4 & Komu było smutno? & Czyli Oli jest smutno. & [bez zastanowienia] Wojtkowi. \\
\hline 5 & Kto był na liście? & $\begin{array}{l}\text { [długo się zastanawia, powta- } \\
\text { rza zdanie] No, to Jacek był na } \\
\text { tej liście. }\end{array}$ & [chwilę się zastanawia] Karol. \\
\hline 6 & $\begin{array}{l}\text { Kto został w przed- } \\
\text { szkolu? }\end{array}$ & $\begin{array}{l}\text { [powtarza zdanie] Basia zosta- } \\
\text { ła? Nie wiem, nie do końca to } \\
\text { rozumiem. }\end{array}$ & [powtarza] No, Kasia. \\
\hline 7 & Kto miał gościa? & No, to może Wojtek. & $\begin{array}{l}\text { [powtarza, zastanawia się] } \\
\text { Tomek. }\end{array}$ \\
\hline 8 & Kto dostał karę? & $\begin{array}{l}\text { [powtarza zdanie] Szczerze } \\
\text { powiem, że nie bardzo rozu- } \\
\text { miem... }\end{array}$ & $\begin{array}{l}\text { [powtarza zdanie trzykrotnie] } \\
\text { Jaś? }\end{array}$ \\
\hline 9 & Kogo poznali rodzice? & $\begin{array}{l}\text { Jezu, nie wiem... chyba Olę. } \\
\text { Ale przyznam szczerze, że zga- } \\
\text { duję. Nie bardzo to rozumiem, } \\
\text { nie wiem, dlaczego tak jest. }\end{array}$ & [powtarza zdanie] Adama. \\
\hline 10 & Kto się śmiał? & $\begin{array}{l}\text { Kuba się śmiał. } \\
\text { [powtarza zdanie] Kuba? Nie... } \\
\text { Kuba został wyśmiany... [zastana- } \\
\text { wia się] No, to Bartek. }\end{array}$ \\
\hline
\end{tabular}

ŹRóDŁo: Opracowanie własne.

W zadaniu tym (tabela 4) oceniano rozumienie konstrukcji składniowych ze stroną bierną. Badany na początku terapii logopedycznej miał ogromne trudności ze zrozumieniem tego typu konstrukcji. Zdarzało się, że podawał prawidłową odpowiedź na pytanie, jednakże w wyniku przypadkowego „strzału”, a nie rozumienia słyszanego zdania. Rok później była widoczna znaczna poprawa w zakresie tej czynności. Pacjent, dzięki dokładnej analizie usłyszanego zdania, poprawnie odpowiedział na większość z zadanych mu pytań. Nie było to dla niego zadanie łatwe, wielokrotnie powtarza frazę, jednak zazwyczaj udzielał trafnej odpowiedzi. Należy wspomnieć, że problemy z rozumieniem opisywanych konstrukcji znacznie się zmniejszały, kiedy pacjent korzystał z wzorca graficznego zdania.

\section{Zadanie 5. Proszę posłuchać czytanych zdań i odpowiedzieć na pytania}

1. Zanim wrócę do domu, zrobię zakupy.

2. Po tym, jak kupiłam sukienkę, wybrałam buty.

3. Zanim Kasia poszła do szkoły, wyprowadziła psa.

4. Po tym, jak obejrzał film, przeczytał książkę.

5. Po remoncie mieszkania wyrzucili stare meble. 
K. Bigos: Dynamika ustępowania zaburzeń afatycznych u chorego po udarze mózgu

6. Zanim uprasowała koszulę, odkurzyła pokój.

7. Po tym, jak umyła włosy, pomalowała paznokcie.

8. Po tym, jak podlała kwiaty, przeczytała gazetę.

9. Zanim zaczęłam się uczyć, posprzątałam mieszkanie i wyrzuciłam śmieci.

10. Po wypiciu kawy podlał ogród.

TABELA 5. Rozumienie struktur językowych w tekstach mówionych - inwersja składniowa

\begin{tabular}{|c|c|c|c|}
\hline \multirow{2}{*}{ Lp. } & \multirow{2}{*}{ Pytanie } & \multicolumn{2}{|c|}{ Odpowiedź } \\
\hline & & na początku terapii & po roku terapii \\
\hline 1 & Co zrobię najpierw? & $\begin{array}{l}\text { [powtarza zdanie] ...wrócę do } \\
\text { domu? }\end{array}$ & $\begin{array}{l}\text { [powtarza zdanie] No to najpierw } \\
\text { zrobię zakupy. }\end{array}$ \\
\hline 2 & Co zrobiłam później? & $\begin{array}{l}\text { [powtarza zdanie] ...wybra- } \\
\text { tam buty? }\end{array}$ & $\begin{array}{l}\text { Jeszcze raz. [B powtórzył zdanie] } \\
\text { Wybrałam buty. }\end{array}$ \\
\hline 3 & Co zrobiła najpierw? & $\begin{array}{l}\text { [powtarza zdanie] Wyprowa- } \\
\text { dziła psa? Ale nie wiem, nie } \\
\text { bardzo rozumiem... }\end{array}$ & Wyprowadziła psa. \\
\hline 4 & Co zrobił najpierw? & $\begin{array}{l}\text { Obejrzat film? Ale to strze- } \\
\text { lam... }\end{array}$ & $\begin{array}{l}\text { Przeczytał książkę? [powtarza } \\
\text { zdanie, zastanawia się] Nie, nie, } \\
\text { obejrzat film! }\end{array}$ \\
\hline 5 & Co zrobili później? & Pewnie te meble wyrzucili. & $\begin{array}{l}\text { No to był remont mieszkania, } \\
\text { a później wyrzucili meble. } \\
\text { To meble. }\end{array}$ \\
\hline 6 & Co zrobiła później? & Odkurzyła pokój? & $\begin{array}{l}\text { [powtarza zdanie, prosi o ponow- } \\
\text { ne przeczytanie] Odkurzyła pokój? } \\
\text { Nie bardzo to rozumiem. }\end{array}$ \\
\hline 7 & Co zrobiła najpierw? & $\begin{array}{l}\text { Umyła głowę? Ale dlaczego tak } \\
\text { jest? Zgaduje, nie wiem tego... }\end{array}$ & $\begin{array}{l}\text { [powtarza zdanie] No, najpierw } \\
\text { włosy umyła. }\end{array}$ \\
\hline 8 & Co zrobiła później? & $\begin{array}{l}\text { Boże, no nie wiem... powiedz- } \\
\text { my, że gazetę przeczytała. }\end{array}$ & $\begin{array}{l}\text { [powtarza zdanie] Czyli później } \\
\text { przeczytała gazetę. }\end{array}$ \\
\hline 9 & $\begin{array}{l}\text { Co zrobiłam naj- } \\
\text { pierw? }\end{array}$ & Zanim... no to sie uczyła. & Posprzątała mieszkanie. \\
\hline 10 & Co zrobił później? & $\begin{array}{l}\text { Podlał ogród? Ale znowu zga- } \\
\text { duję. }\end{array}$ & $\begin{array}{l}\text { Kawy napił się najpierw? [powta- } \\
\text { rzam zdanie] No, ja nie wiem, bo } \\
\text { najpierw wypił tę kawę, a później } \\
\text { podlał ogród, ale ja nie wiem, co } \\
\text { było później. }\end{array}$ \\
\hline
\end{tabular}

ŹRóDŁo: Opracowanie własne.

Tabela 5 zawiera wyniki badania rozumienia zdań z inwersją składniową. W przypadku tego zadania również zauważalna jest wyraźna dynamika ustępowa- 
nia zaburzeń rozumienia. Na początku terapii zdania z inwersją składniową były dla pacjenta całkowicie niezrozumiałe, żadnej z odpowiedzi nie udzielił z przekonaniem, każda stanowiła jedynie próbę odgadnięcia skomplikowanej zagadki. Po roku intensywnej pracy była widoczna znaczna poprawa $\mathrm{w}$ rozumieniu tego typu konstrukcji, jednakże badany wkładał duży wysiłek w wykonanie zadania wielokrotnie powtarzał zdanie i poddawał je analizie. Podobnie jak wcześniej, zadanie stawało się mniej skomplikowane wówczas, gdy pacjent samodzielnie czytał podane zdania.

\section{Zadanie 6. Proszę posłuchać czytanych zdań i powiedzieć, jak je Pan rozumie}

TABELA 6. Rozumienie struktur językowych w tekstach mówionych - zdania z podwójnym przeczeniem

\begin{tabular}{|c|c|c|c|}
\hline \multirow{2}{*}{ Lp. } & \multirow{2}{*}{ Zdanie } & \multicolumn{2}{|c|}{ Odpowiedź } \\
\hline & & na początku terapii & po roku terapii \\
\hline 1 & Nie wierzę w nic. & Nie wierze $w$ nic? To to $w$ nic. & No $w$ nic nie wierzy. \\
\hline 2 & $\begin{array}{l}\text { Nieprawda, że nie pójdę } \\
\text { do kina. }\end{array}$ & Nie pójdzie do kina. & $\begin{array}{l}\text { Nie pójdzie do tego kina. W ogóle } \\
\text { nie pójdzie... chociaż, czy ja } \\
\text { wiem... chyba jednak pójdzie. }\end{array}$ \\
\hline 3 & $\begin{array}{l}\text { Nigdy nie byłam w } \\
\text { Holandii. }\end{array}$ & Nie była $w$ Holandii. & Nie była w tej Holandii. \\
\hline 4 & $\begin{array}{l}\text { Nikt nie pojedzie na } \\
\text { wycieczkę. }\end{array}$ & $\begin{array}{l}\text { Czyli, że pojedzie? Czy nie } \\
\text { pojedzie? }\end{array}$ & No, to nie pojedzie nikt i kropka. \\
\hline 5 & $\begin{array}{l}\text { Nie noszę niewygod- } \\
\text { nych butów. }\end{array}$ & $\begin{array}{l}\text { No czyli, że nie noszę wygod- } \\
\text { nych. }\end{array}$ & Noszę wygodne. \\
\hline 6 & Nikt tego nie wie. & No, że nikt nie wie. & No, nie wie i koniec. \\
\hline 7 & $\begin{array}{l}\text { Nie umiem niedbale } \\
\text { sprzątać. }\end{array}$ & Że sprząta niedbale. & $\begin{array}{l}\text { No, źle sprzątam. Aha, nie, nie! } \\
\text { Czyli, że właśnie dobrze sprzątam. }\end{array}$ \\
\hline 8 & $\begin{array}{l}\text { Niemożliwe, żeby nie } \\
\text { odrobiła zadania. }\end{array}$ & Pewnie zawsze odrabia. & No, odrobiła to zadanie. \\
\hline 9 & Nic na to nie wskazuje. & Że na coś wskazuje? & $\begin{array}{l}\text { [powtarza zdanie] No, nic się nie } \\
\text { stało. }\end{array}$ \\
\hline 10 & Nikomu nic do tego. & $\begin{array}{l}\text { Że ktoś ma coś do powiedze- } \\
\text { nia? }\end{array}$ & $\begin{array}{l}\text { No, że ktoś może się wypowiadać. } \\
\text { A nieee! To jest moja sprawa } \\
\text { i nikomu nic do tego. }\end{array}$ \\
\hline
\end{tabular}

ŹRóDŁo: Opracowanie własne.

Rozumienie zdań z podwójnym przeczeniem, stanowiące przedmiot badania w kolejnej próbie (tabela 6), przysparza trudności nie tylko pacjentom $\mathrm{z}$ afazją. 
Z punktu widzenia logiki formalnej podwójne przeczenie oznacza bowiem prawdziwe twierdzenie (Stanosz, 2005), co z kolei nie zawsze potwierdza się w języku polskim. Badany pacjent na początku terapii logopedycznej miał znaczne trudności w rozumieniu tego typu konstrukcji. Poprawnie odczytywał znaczenie mniej niż połowy zdań, przy czym nie był pewien swoich odpowiedzi. Po rocznej pracy terapeutycznej sytuacja się zmieniła. Badany prawidłowo rozpoznał sens większości podanych konstrukcji. Nawet jeśli się mylił, po głębszej analizie zmieniał zdanie i korygował swoją wypowiedź.

\section{Zadanie 7. Proszę posłuchać i powiedzieć, kim są dla Pana osoby, które zostaną wymienione}

TABELA 7. Rozumienie struktur językowych w tekstach mówionych - związki rządu

\begin{tabular}{|c|c|c|c|}
\hline \multirow{2}{*}{ Lp. } & \multirow{2}{*}{ Osoba } & \multicolumn{2}{|c|}{ Odpowiedź } \\
\hline & & na początku terapii & po roku terapii \\
\hline 1 & brat ojca & $\begin{array}{l}\text { No, nie wiem, czy sobie z tym poradze... } \\
\text { Nie wiem, jak to jest... [B: To wujek czy } \\
\text { dziadek?] No, to może dziadek? Ale nie } \\
\text { wiem, kompletnie tego nie rozumiem... }\end{array}$ & Wujek. \\
\hline 2 & siostra matki & $\begin{array}{l}\text { [powtarza frazę kilkukrotnie] Nie wiem, } \\
\text { pojęcia nie mam. [B: To babcia czy cio- } \\
\text { cia?] To takie coś będzie? [powtarza frazę } \\
\text { ponownie] Nie, no to... siostra matki, to } \\
\text { no... no to ta siostra matki, ale nie wiem, } \\
\text { jak to nazwać, jak Pani mówita? [B: Bab- } \\
\text { cia czy ciocia?] Babcia, czy ciocia... No, } \\
\text { to może babcia, ale ja nie wiem, nie dam } \\
\text { głowy, dlaczego tak jest. }\end{array}$ & [powtarza frazę] Ciotka. \\
\hline 3 & syn matki & $\begin{array}{l}\text { To, kto to może być? Nie wiem, nie } \\
\text { trafię. [zastanawia się; B: To brat czy } \\
\text { kuzyn?] No, to może brat... [B: Tak!] } \\
\text { No, tak, ale to trzeba trafić. Dlaczego ja } \\
\text { to mam zgadnać, ja tego nie wiem... Nie } \\
\text { potrafię. W ogóle tego nie rozumiem... }\end{array}$ & $\begin{array}{l}\text { [powtarza frazę] Wujek? Nie... } \\
\text { Syn mojej matki... To ja jestem? } \\
\text { [B: Pan też, ale i...?] Nie, no, chwi- } \\
\text { leczkę... brat? }\end{array}$ \\
\hline 4 & wnuk żony & $\begin{array}{l}\text { O, Boże... [powtarza frazę, zastanawia } \\
\text { się] No, właśnie nie wiem, jak to okreś- } \\
\text { lić... Nie rozumiem tych Pani pytań. }\end{array}$ & $\begin{array}{l}\text { [powtarza frazę] No, to mój... } \\
\text { [powtarza frazę] No, to jest A.*, } \\
\text { to ja wiem, kto to jest. No, to dla } \\
\text { mnie wnuczek. }\end{array}$ \\
\hline 5 & ojciec brata & $\begin{array}{l}\text { Wujek? Nie? [powtarza frazę kilku- } \\
\text { krotnie] Może jakiś wujek? Nie, nie } \\
\text { wujek? To ja nie wiem, jak to jest. }\end{array}$ & Stryjek jakiś? Coś takiego. \\
\hline
\end{tabular}


cd. tabeli 7

\begin{tabular}{|c|l|l|l|}
\hline 6 & matka siostry & $\begin{array}{l}\text { Już mi się wszystko pomieszało... To nie } \\
\text { jest babka? }\end{array}$ & $\begin{array}{l}\text { To jest ciotka. Nie? Ale moment, } \\
\text { ja mam siostrę, H.* [B: No, właś- } \\
\text { nie, więc jej mama kim jest dla } \\
\text { Pana?] Jej mama... [zastanawia } \\
\text { się] No, to przecież i moja mama, } \\
\text { tak? [B: Tak!] No, to trzeba było } \\
\text { od razu tak mówić! }\end{array}$ \\
\hline 7 & matka ojca & To może to babka? & [powtarza frazę] Babcia. \\
\hline 8 & syn wujka & $\begin{array}{l}\text { [powtarza frazę kilkukrotnie] No, właś- } \\
\text { nie nie wiem, kto to jest... Jeżeli to jest } \\
\text { syn wujka, tak? No nie wiem, napraw- } \\
\text { dę, nie potrafię tego powiedzieć. }\end{array}$ & $\begin{array}{l}\text { [powtarza frazę kilkukrotnie] Kto } \\
\text { to jest? [B: Brat czy kuzyn?] A, no } \\
\text { to kuzyn. }\end{array}$ \\
\hline 10 & siostra ojca & $\begin{array}{l}\text { Dużo ma Pani jeszcze tych przykładów? } \\
\text { Ja naprawdę tego nie potrafię odgad- } \\
\text { nać... }\end{array}$ & $\begin{array}{l}\text { No, to siostra to to pewnie nie jest, tak? } \\
\text { Nie wiem, może ten ojciec? }\end{array}$ \\
\hline
\end{tabular}

* Pacjent podaje imię członka swojej rodziny.

ŹRóDŁo: Opracowanie własne.

Tabela 7 przedstawia wyniki badania rozumienia znaczenia relacji, jakie zachodzą $\mathrm{w}$ wymienionych przykładach związków rządu ${ }^{6}$. W chwili podjęcia terapii logopedycznej tego typu konstrukcje sprawiały pacjentowi ogromną trudność. W zasadzie nie był on w stanie poprawnie rozpoznać żadnej z podanych relacji. Pomocne wówczas stało się odniesienie do członków najbliższej rodziny badanego i ich imion. Jedynym mechanizmem kompensacyjnym $w$ tym przypadku okazało się tworzenie „drzewek genealogicznych”, dzięki którym badany mógł zrozumieć korelacje, jakie zachodzą w podanych związkach. Tego typu oddziaływania stały się podstawą rozumienia tych struktur językowych. Po rocznej terapii mowy badany popełniał nieliczne błędy, świadomie analizował każdą strukturę i zazwyczaj poprawnie ją interpretował. Jego odpowiedzi były przemyślane, zdecydowanie rzadziej potrzebował podpowiedzi, a jeśli taką otrzymał, w pełni ją wykorzystywał.

${ }^{6}$ Związek rządu - związek wyrazowy, w którym wyraz podrzędny przybiera przypadek, jakiego wymaga wyraz nadrzędny. 


\section{Zadanie 8. Proszę posłuchać czytanych zdań i odpowiedzieć na pytania}

1. Cukier jest tańszy od kawy, ale droższy od budyniu.

2. Koszula jest droższa od spodni, ale tańsza od butów.

3. Kasia jest wyższa od Basi, ale niższa od Karola.

4. Ania jest cięższa od Zosi, ale lżejsza od Darka.

5. Julek jest starszy od Maćka, ale młodszy od Ali.

6. Pralka jest tańsza od lodówki, ale droższa od suszarki.

7. Basia jest młodsza od Joasi, ale starsza od Oli.

8. Kuba jest wyższy od Tomka, ale niższy od Bartka.

9. Labrador jest większy od kundelka, ale mniejszy od owczarka.

10. Asia jest niższa od Kasi, ale wyższa od Zosi.

TABELA 8. Rozumienie struktur językowych w tekstach mówionych - struktury porównawcze

\begin{tabular}{|c|c|c|c|}
\hline \multirow{2}{*}{ Lp. } & \multirow{2}{*}{ Pytanie } & \multicolumn{2}{|c|}{ Odpowiedź } \\
\hline & & na początku terapii & po roku terapii \\
\hline 1 & $\begin{array}{l}\text { Co kosztuje naj- } \\
\text { mniej? }\end{array}$ & $\begin{array}{l}\text { [śmieje się] A skąd ja mam to wie- } \\
\text { dzieć... Nie wiem... }\end{array}$ & $\begin{array}{l}\text { [rozpisuje na kartce] Czyżby } \\
\text { budyń? }\end{array}$ \\
\hline 2 & Co jest najdroższe? & $\begin{array}{l}\text { [powtarza zdanie kilkukrotnie] } \\
\text { A na to da się w ogóle odpowie- } \\
\text { dzieć? Pani potrafi? }\end{array}$ & $\begin{array}{l}\text { [rozpisuje na kartce] Wychodzi } \\
\text { na to, że buty. }\end{array}$ \\
\hline 3 & $\begin{array}{l}\text { Kto jest średniego } \\
\text { wzrostu? }\end{array}$ & $\begin{array}{l}\text { [rozpisuje na kartce] Nie mam } \\
\text { pojęcia, w ogóle tego nie rozu- } \\
\text { miem... }\end{array}$ & $\begin{array}{l}\text { Jezu, tak bez zapisywania, to } \\
\text { chyba nie trafię! Ale, hmm... } \\
\text { ta pierwsza dziewczyna wydaje } \\
\text { się być średnia. }\end{array}$ \\
\hline 4 & Kto waży najmniej? & $\begin{array}{l}\text { [rozpisuje na kartce] Wychodzi na } \\
\text { to, że ten trzeci. }\end{array}$ & Darek? \\
\hline 5 & Kto jest najmłodszy? & $\begin{array}{l}\text { [rozpisuje na kartce] Czyli, że ten } \\
\text { Julek, tak? }\end{array}$ & Najmłodsza chyba jest Ala. \\
\hline 6 & $\begin{array}{l}\text { Co jest w średniej } \\
\text { cenie? }\end{array}$ & $\begin{array}{l}\text { [rozpisuje na kartce] Zgaduję, że } \\
\text { lodówka, ale pewnie źle zgaduję. }\end{array}$ & $\begin{array}{l}\text { No, chyba pralka, ale nie jestem } \\
\text { pewien. }\end{array}$ \\
\hline 7 & Kto jest najstarszy? & $\begin{array}{l}\text { [rozpisuje na kartce] Strzelam, } \\
\dot{z} e \text { Ola. }\end{array}$ & Ola. \\
\hline 8 & Kto jest najniższy? & $\begin{array}{l}\text { [rozpisuje na kartce] No nie wiem, } \\
\text { nie umiem sobie z tym poradzić... }\end{array}$ & To Tomek chyba. \\
\hline 9 & $\begin{array}{l}\text { Który z nich jest naj- } \\
\text { mniejszy? }\end{array}$ & $\begin{array}{l}\text { [powtarza zdanie wielokrotnie] } \\
\text { To może ten kundel? }\end{array}$ & Labrador. \\
\hline 10 & $\begin{array}{l}\text { Kto jest średniego } \\
\text { wzrostu? }\end{array}$ & Zosia. & Może Kasia? \\
\hline
\end{tabular}

ŹRóDŁo: Opracowanie własne. 
W tabeli 8 przedstawiono wyniki badania rozumienia najbardziej złożonych pod względem logiczno-gramatyczno-formalnym struktur, a mianowicie struktur porównawczych. Zadanie 8 okazało się dla pacjenta najtrudniejsze - zarówno w czasie, gdy rozpoczynał terapię logopedyczną, jak i po roku jej trwania. Rozumienie struktur porównawczych przez mężczyznę się poprawiło, jednakże po roku nadal stanowiło dla niego dużą trudność. Pomocne okazało się graficzne przedstawianie zdań - wówczas pacjent popełniał mniej błędów.

\section{Zadanie 9. Proszę wykonać polecenia}

TABELA 9. Rozumienie struktur językowych w tekstach mówionych - wyrażenia przyimkowe

\begin{tabular}{|c|c|c|c|}
\hline \multirow{2}{*}{ Lp. } & \multirow{2}{*}{ Polecenie } & \multicolumn{2}{|c|}{ Wykonanie } \\
\hline & & na początku terapii & po roku terapii \\
\hline 1 & $\begin{array}{l}\text { Proszę położyć długopis na } \\
\text { kartce. }\end{array}$ & $\begin{array}{l}\text { Wykonuje czynność popraw- } \\
\text { nie }\end{array}$ & $\begin{array}{l}\text { Wykonuje czynność } \\
\text { poprawnie }\end{array}$ \\
\hline 2 & $\begin{array}{l}\text { Proszę położyć długopis pod } \\
\text { kartką. }\end{array}$ & $\begin{array}{l}\text { Wykonuje czynność popraw- } \\
\text { nie }\end{array}$ & $\begin{array}{l}\text { Wykonuje czynność } \\
\text { poprawnie }\end{array}$ \\
\hline 3 & $\begin{array}{l}\text { Proszę położyć klucze na dole } \\
\text { kartki. }\end{array}$ & $\begin{array}{l}\text { Wykonuje czynność popraw- } \\
\text { nie }\end{array}$ & $\begin{array}{l}\text { Wykonuje czynność } \\
\text { poprawnie }\end{array}$ \\
\hline 4 & $\begin{array}{l}\text { Proszę położyć długopis } \\
\text { z lewej strony kartki. }\end{array}$ & $\begin{array}{l}\text { Wykonuje czynność popraw- } \\
\text { nie }\end{array}$ & $\begin{array}{l}\text { Wykonuje czynność } \\
\text { poprawnie }\end{array}$ \\
\hline 5 & $\begin{array}{l}\text { Proszę położyć klucze pomię- } \\
\text { dzy długopisem a kartką. }\end{array}$ & $\begin{array}{l}\text { Po dłuższym zastanowieniu } \\
\text { wykonuje czynność poprawnie }\end{array}$ & $\begin{array}{l}\text { Wykonuje czynność } \\
\text { poprawnie }\end{array}$ \\
\hline 6 & $\begin{array}{l}\text { Proszę położyć klucze na } \\
\text { kartce, a obok kluczy położyć } \\
\text { długopis. }\end{array}$ & Wymaga pomocy & $\begin{array}{l}\text { Wykonuje czynność } \\
\text { poprawnie }\end{array}$ \\
\hline 7 & $\begin{array}{l}\text { Proszę długopisem dotknąć } \\
\text { kartki. }\end{array}$ & $\begin{array}{l}\text { Myli się, po podpowiedzi } \\
\text { wykonuje czynność poprawnie }\end{array}$ & $\begin{array}{l}\text { Wykonuje czynność } \\
\text { poprawnie }\end{array}$ \\
\hline 8 & $\begin{array}{l}\text { Po tym, jak położy Pan/Pani } \\
\text { długopis obok kartki, proszę } \\
\text { położyć klucze przed kartką. }\end{array}$ & Wymaga pomocy & $\begin{array}{l}\text { Po dłuższym zastanowie- } \\
\text { niu i niewielkiej pomo- } \\
\text { cy wykonuje czynność } \\
\text { poprawnie }\end{array}$ \\
\hline 9 & $\begin{array}{l}\text { Zanim dotknie Pan/Pani dłu- } \\
\text { gopisem kluczy, proszę poło- } \\
\text { żyć klucze na kartce. }\end{array}$ & Wymaga pomocy & Wymaga pomocy \\
\hline 10 & $\begin{array}{l}\text { Proszę położyć kartkę obok } \\
\text { kalendarza, a następnie, } \\
\text { pomiędzy, proszę położyć } \\
\text { klucze. }\end{array}$ & Wymaga pomocy & Wymaga pomocy \\
\hline
\end{tabular}

ŹródŁo: Opracowanie własne. 
Tabela 9 przedstawia wyniki badania rozumienia znaczenia wyrażeń przyimkowych. W czasie rozpoczynania terapii logopedycznej pacjent był w stanie samodzielnie wykonać tylko proste polecenia, potrzebował pomocy w wykonaniu poleceń bardziej skomplikowanych, wymagających orientacji logiczno-gramatycznej i czasowo-przestrzennej. $Z$ czasem rozumienie tych struktur językowych się poprawiło. Badany potrzebował pomocy tylko w przypadku najbardziej skomplikowanych poleceń, zawierających inwersję składniową oraz mających złożoną strukturę logiczno-gramatyczno-formalną.

\section{Podsumowanie wyników badań}

Przedstawiony wykres ukazuje stosunek poleceń prawidłowo wykonanych przez chorego $\mathrm{z}$ afazją semantyczną $\mathrm{w}$ przypadku poszczególnych zadań $\mathrm{w}$ chwili rozpoczęcia oddziaływań terapeutycznych do tych wykonanych poprawnie po rocznej intensywnej pracy z pacjentem.

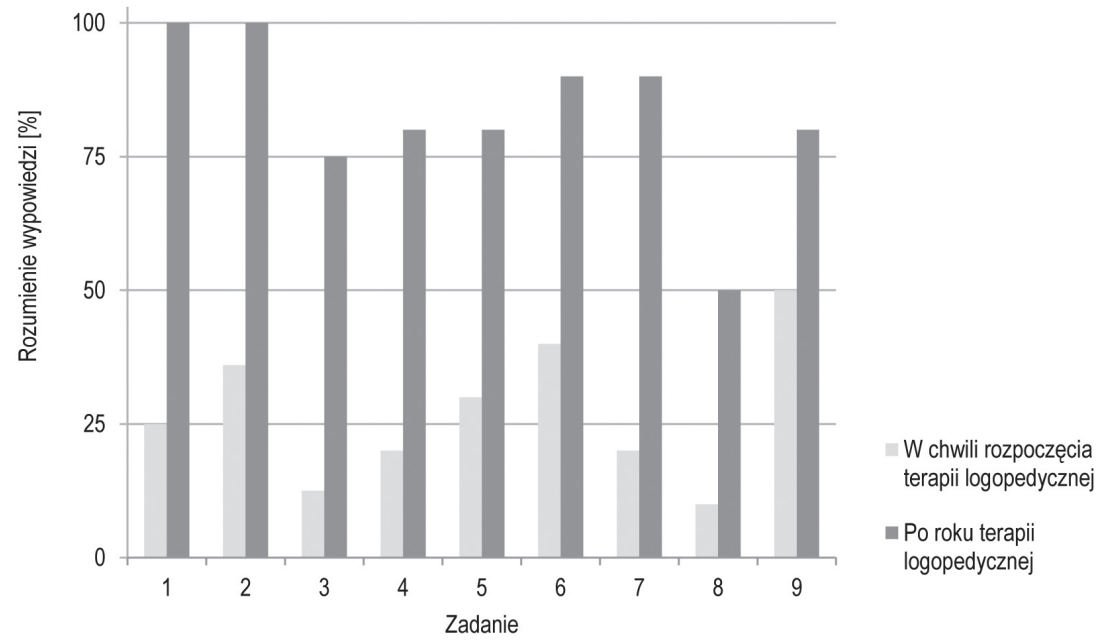

Wykres 1. Dynamika ustępowania zaburzeń rozumienia wypowiedzi mówionych u pacjenta $\mathrm{z}$ afazją semantyczną

Cyfry odnoszą się do poziomu rozumienia wypowiedzi w poszczególnych zadaniach, dotyczących następujących kategorii: 1) funkcje pragmatyczne wypowiedzi; 2) teksty o znaczeniu dosłownym; 3) teksty o znaczeniu metaforycznym; 4) konstrukcje ze stroną bierną; 5) zdania z inwersją składniową; 6) zdania z podwójnym przeczeniem; 7) związki rządu; 8) struktury porównawcze; 9) wyrażenia przyimkowe.

ŹRóDŁo: Opracowanie własne.

Zaprezentowane wyniki badań przeprowadzone na podstawie autorskich prób eksperymentalno-klinicznych dotyczących rozumienia zarówno dłuższych 
wypowiedzi, jak i krótszych struktur językowych o różnym poziomie złożoności gramatycznej wskazują na znaczną dynamikę ustępowania zaburzeń w zakresie czynności rozumienia u badanego mężczyzny. Pacjentom $\mathrm{z}$ afazją semantyczną, w której zaburzeniu ulega synteza symultatywna, czyli zdolność jednoczesnej analizy informacji językowych pod względem logicznym, gramatycznym i formalnym, największe problemy sprawia rozumienie złożonych gramatycznie form wypowiedzi, co potwierdza zaprezentowany $\mathrm{w}$ artykule przypadek. $\mathrm{U}$ badanego po roku intensywnej terapii logopedycznej, pomimo znacznego zmniejszenia się deficytów odbioru wypowiedzi, wciąż obserwuje się trudności (choć znacznie mniejsze) w rozumieniu struktur o najwyższym poziomie złożoności, szczególnie struktur porównawczych, związków rządu, zdań z inwersją składniową czy wyrażeń przyimkowych o rozbudowanej treści. Największe postępy można stwierdzić w zakresie rozumienia znaczenia dłuższych wypowiedzi mówionych, zarówno tekstów dialogowych (ocenie poddano rozumienie funkcji pragmatycznych - informacyjnej, działania, modalnej i emocjonalnej), jak i monologowych (o znaczeniu dosłownym i metaforycznym; ocenę odniesiono do czterech poziomów rozumienia tekstu - globalnego, selektywnego, szczegółowego i interakcyjnego).

\section{Zakończenie}

Postępy w terapii mowy w omawianym przypadku wynikają z czynników organicznych (stosunkowo niewielki obszar uszkodzenia mózgu), jak też z okoliczności, w jakich znalazł się chory (doskonała opieka domowa i regularna terapia logopedyczna). Wpływ mają także czynniki społeczne (wiek badanego, wykształcenie wyższe techniczne, sprzyjające środowisko, w jakim przebywa) oraz ogromna motywacja pacjenta, jego pracowitość i determinacja w przełamywaniu swoich ograniczeń, a także ogromne wsparcie i zaangażowanie rodziny.

Dynamiczne zmiany w obrazie zaburzeń, wycofywanie się objawów afatycznych, dobry stan kliniczny, coraz większa aktywność życiowa pacjenta oraz jego ogromna motywacja są podstawą pozytywnych prognoz.

Podjęty w artykule temat składa się na szerszą problematykę prowadzonych przeze mnie badań, które dotyczą oceny czynności rozumienia wypowiedzi mówionych i pisanych przez osoby, u których, w wyniku ogniskowych uszkodzeń mózgu w obrębie obszaru mowy (u osób praworęcznych - zwykle środkowej części lewej półkuli), wystąpiła afazja. Wybór tematu jest uwarunkowany potrzebami zarówno poznawczymi, jak i społecznymi. Na gruncie badań logopedycznych proponowane zagadnienie nie zostało poddane dotychczas głębszej 
analizie. Afazja, jako zespół objawów zaburzeń językowych, to zjawisko opisywane w ramach różnych dyscyplin naukowych, większość badaczy koncentruje się jednak na procesie nadawania mowy. W literaturze przedmiotu brakuje natomiast analiz dotyczących swoistych zaburzeń rozumienia wypowiedzi mówionych i pisanych w przypadkach afazji.

Praktyka logopedyczna pokazuje, że ograniczenia w odbiorze wypowiedzi dotyczą nie tylko chorych $\mathrm{z}$ afazją sensoryczną, jak powszechnie się uważa, ale widoczne są także u pacjentów, u których zdiagnozowano afazję motoryczną. Takie wnioski wskazują z kolei na potrzebę prowadzenia badań w zakresie czynności rozumienia u osób $\mathrm{z}$ afazją zarówno sensoryczną, jak i motoryczną, a następnie - konieczność nowego opisu poszczególnych typów afazji.

Należy też pamiętać, że ocena rozumienia jest jednym z podstawowych celów diagnozy logopedycznej, a w przypadku stwierdzenia zaburzeń tej czynności usprawnianie jej staje się pierwszym celem terapii logopedycznej. Mam zatem nadzieję, że wyniki podjętych badań przyczynią się do pogłębienia wiedzy na temat stanu rozumienia wypowiedzi u osób $\mathrm{z}$ afazją, a także staną się cenną wskazówką dla logopedów i neurologopedów w pracy z pacjentami nad przełamywaniem barier w dostępie do słowa.

\section{Bibliografia}

Bartmiński, J., Niebrzegowska-Bartmińska, S. (2009). Tekstologia. Warszawa: Wydawnictwo Naukowe PWN.

BĄK, P. (2010). Gramatyka języka polskiego. Warszawa: Wiedza Powszechna.

Bochenek, A., Reicher, M. (1981). Anatomia człowieka. T. IV: Układ nerwowy ośrodkowy. Warszawa: Wydawnictwo Lekarskie PZWL.

Boniecka, B. (2000). Struktura i funkcje pytań. Lublin: Wydawnictwo Uniwersytetu Marii Curie-Skłodowskiej.

Chodkiewicz, H. (1986). O sprawności czytania w nauczaniu języka obcego. Warszawa: Wydawnictwa Szkolne i Pedagogiczne.

Drabik, L., Sobol, E. (2007). Słownik języka polskiego. Warszawa: Wydawnictwo Naukowe PWN.

GoŁĄB, B. (2004). Anatomia czynnościowa ośrodkowego układu nerwowego. Warszawa: Wydawnictwo Lekarskie PZWL.

Gra BIAS, S. (2019). Język w zachowaniach społecznych. Podstawy socjolingwistyki i logopedii. Lublin: Wydawnictwo Uniwersytetu Marii Curie-Skłodowskiej.

Grabias, S. (2007). Język, poznanie, interakcja. W: T. Woźniak, A. DomagaŁa (red.), Mowa. Teoria - praktyka. Język, interakcja, zaburzenia mowy. Metodologia badań (t. 2, s. 355-377). Lublin: Wydawnictwo Uniwersytetu Marii Curie-Skłodowskiej.

Grabias, S. (1997). Mowa i jej zaburzenia. Lublin: Wydawnictwo Uniwersytetu Marii Curie-Skłodowskiej. 
Grabias, S., (2012). Teoria zaburzeń mowy. Perspektywy badań, typologie zaburzeń, procedury postępowania logopedycznego. W: S. Grabias, Z.M. Kurkowski (red.), Logopedia. Teoria zaburzeń mowy (s. 15-72). Lublin: Wydawnictwo Uniwersytetu Marii Curie-Skłodowskiej.

KąDZielawa, D. (1983). Czynność rozumienia mowy. Analiza neuropsychologiczna. Wrocław: Ossolineum.

Konorski, J. (1969). Integracyjna działalność mózgu. Warszawa: PWN.

Łuria, A.R, (1976). Podstawy neuropsychologii. [Tłum. D. KęDZielawa]. Warszawa: PZWL.

Maruszewski, M. (1966). Afazja. Zagadnienia teorii i terapii. Warszawa: PWN.

Maruszewski, M. (1970). Mowa a mózg. Zagadnienia neuropsychologiczne. Warszawa: PWN.

Panasiuk, J. (2012). Diagnoza logopedyczna w przebiegu chorób neurologicznych u osób dorosłych. W: E. Czaplewska, S. Milewski (red.), Diagnoza logopedyczna. Podręcznik akademicki (s. 263-324). Gdańsk: Harmonia Universalis.

PANASIUK, J. (2013). Afazja a interakcja. TEKST - metaTEKST - konTESKT. Lublin: Wydawnictwo Uniwersytetu Marii Curie-Skłodowskiej.

Panasiuk, J. (2015). Standard postępowania logopedycznego w afazji. W: S. Grabias, J. Panasiuk, T. WoźNiak (red.), Logopedia. Standardy postępowania logopedycznego (s. 869-916). Lublin: Wydawnictwo Uniwersytetu Marii Curie-Skłodowskiej.

Panasiuk, J., Woźniak, T. (2002). Pojęcie tekstu a zaburzenia mowy. W: S. Grabias (red.), Zaburzenia mowy. Mowa. Teoria. Praktyka (t. 1, s. 108-132). Lublin: Wydawnictwo Uniwersytetu Marii Curie-Skłodowskiej.

Polkowska, A. (1993). Rozumienie tekstu. W: I. Kurcz (red.), Psychologia a semiotyka. Pojęcia i zagadnienia (s. 266-267). Warszawa: Zakład Semiotyki Logicznej Uniwersytetu Warszawskiego „Znak. Język. Rzeczywistość”.

Prusiński, A. (1980). Podstawy neurologii klinicznej. Warszawa: PZWL.

Seretny, A., Lipińska, E. (2005). ABC metodyki nauczania języka polskiego jako obcego. Kraków: Universitas.

Stanosz, B. (2005). Wprowadzenie do logiki formalnej. Podręcznik dla humanistów. Warszawa: Wydawnictwo Naukowe PWN.

Walsh, K. (1998). Neuropsychologia kliniczna. Tłum. B. Mroziak. Warszawa: Wydawnictwo Naukowe PWN.

WojCiechowsKa, J. (2014). Metodologiczne podstawy badań nad rozumieniem w pragnozji. Forum Logopedyczne, 22, 35-44.

Wojciechowska, J. (2015). Ocena rozumienia tekstu w praktyce logopedycznej. Logopedia Silesiana, 4, 304-318. 